\title{
WPS3169
}

Second draft

May 2003

\section{Is inequality in Africa really different?}

\author{
Branko Milanovic ${ }^{1}$
}

High inequality in Africa is something of a paradox: Africa should be a low-inequality continent according to the Kuznets hypothesis (because African countries are poor and agriculture-based), and also because land (the main asset) is widely shared. Our hypothesis is that African inequality is politically determined. Yet in the empirical analysis, despite the introduction of several political variables, there is still an inequality-increasing "Africa effect" linked to ethnic fractionalization. The politics however may work through ethnic fractionalization which provides an easy and secure basis for formation of political groups. Although this is a plausible explanation, it is not fully satisfactory and is criticized in the concluding section.

Keywords: Africa, inequality, ethnic fractionalization

JEL classification: D31, O55, O15

\footnotetext{
${ }^{1}$ World Bank, Development Research Group. The paper represents author's own views only; the views should not be attributed to the World Bank or its affiliated organization. I am grateful to Nancy Birdsall, Luc Christiansen, Alan Gelb, Amar Hamoudi, Mark Gradstein, Mansoob Murshed, Stefano Paternostro, Nicolas van de Walle and Bernard Wasow for very helpful comments.
} 


\section{Introduction}

That African countries have a relatively high inequality — among the highest in the world-is generally well known. Yet, at further reflection, this fact represents a puzzle that has been little researched. This may be simply due to the fact that while writings on inequality and poverty in individual African countries have recently become much more common, not least thanks to a much greater availability of household surveys within the World Bank, continent-wide (or several-country) studies of inequality are rare (the exceptions are Demery and Squire 1996; Christiaensen, Demery and Paternostro, 2002).

One would expect Africa to have rather a very low inequality. If one subscribes to a Kuznets type of a relationship, Africa, being relatively poor and with a large share of agricultural population, should be on very much on the left of the rising portion of the Kuznets curve: inequality should be relatively low. In addition, the main asset, agricultural land, is relatively evenly distributed in Africa. In part thanks to the tradition of communal-land holding and exploitation, and absence of large plantations, landlessness has never been an issue in Africa. Mkandawire (2002, p. 193) writes: "There are two striking features of the African countryside...The first is that peasants...have direct access to the main means of production-labour and land; and the second [that]...with the exception of countries of settler agriculture and concessions, production of export crops in much of colonial Africa has remained in the hands of peasants." Actually, the absence of a landless peasant class was the major obstacle for a socialist revolution in the African context as noted by Che Guevara during his attempt to ignite the fires of the revolution in the Congo (quoted by Mkandawire, 2002, p.194). ${ }^{2}$

\footnotetext{
${ }^{2}$ As Mkandawire (2002, p.199) writes, explaining the lack of appeal of socialism to African peasants, "[g]uerillas cannot offer an immediate end to predation by local potentates, since such predation hardly exists; nor can they liberate peasants from the heavy exaction of national governments, since African governments have only extracted surplus through the market and not by direct taxation at the level of production."
} 
It is precisely this contrast between peasants in Africa and Latin America that Che must have found unexpected, and perplexing, that also informs our view on income inequality in Africa. Had European colonists managed to create extensive plantations along the west coast of Africa, ${ }^{3}$ African and Latin American land ownership structures would have been more similar, and broadly the same level of inequality would be expected. Similarly, we are not particularly puzzled by very the high levels of inequality that obtain in Zimbabwe and South Africa where Europeans did manage to create a strong presence, a two-tier society and where independence or abolishment of the apartheid took much longer than elsewhere in Africa. What is doubly puzzling (in view of the Kuznets hypothesis, and broad ownership of land) is high levels of inequality in the rest of sub-Saharan Africa.

The hypothesis that we want to test in this paper is that high inequality in Africa is principally a political phenomenon. ${ }^{4}$ Historically, African societies have been hierarchical with a large power vested in top leaders. Prevalence of slavery, conducted both by Muslim traders and later by European colonists, rested on active collaboration of African chiefs who often sold their own subjects into slavery as a way of acquiring money and power (see e.g. Bairoch, 1997, vol. 2). This very fact denotes a very hierarchical social organization. Hierarchical structure was reinforced by European colonialism. European colonists became the new rulers, whose affinitive links to the bulk of the population were all but inexistent. ${ }^{5}$ The population was again seen as a perfect

\footnotetext{
${ }^{3}$ However, the effects of this failure were not benign. It only added a further stimulus to the slave trade as Europeans needed slaves to work on the plantations in the Americas. As Behrendt, Eltis and Richardson (2001, p. 474) write, "European weakness [inability to establish plantations on the continent] in the face of African political and military realities, coupled with..Europeans' taste for plantation produce, created the labour shortage that the slave trade filled."

${ }^{4}$ Gelb (2001) writes that there is a consensus that principal causes of Africa's economic decline are political. Nkurunziza and Ngaruko (2002) in a detailed study of Burundi's growth 1960-2000 come to the same conclusion and write (page 1): "The usual economic factors explaining growth are endogeneous to political decisions, suggesting that it is politics not economics that explains the dismal performance." The origin of the view that it is the politics that is behind the African "dummy variable" (significantly worse growth performance compared to the rest of the world) goes back to the World Bank Berg Report (1981), and Bates (1981) (see Arrighi, 2001).

${ }^{5}$ As Hobson (1965 [1902]) put it in his classic Imperialism, "The normal state of such a country [in Africa] is one in which the most fertile lands and the mineral resources are owned by white aliens and worked by natives under their direction, primarily for their gain: they do not identify themselves with the interest of
} 
subject for exploitation - be it through forced labor, slavery, or a combination of the two. Colonial administration reinforced the traditional hierarchical structure of African societies in order to better control the population. A mutual cooperation between the two elites, the traditional African and the new European, thus developed to the detriment of the majority of the population. Finally, after the independence it seemed for a while that a much more egalitarian system would emerge. A number of African leaders of the 1960's (Nkrumah in Ghana, Sekou Touré in Guinea, Nyerere in Tanzania) espoused socialismwhich, as we know, has elsewhere resulted in large leveling of income even if political power was highly concentrated. Indeed, in a few African countries, like Tanzania and Zambia, more egalitarian policies were adopted and inequality levels seem moderate. Yet in most of the continent, despite these early promises of egalitarianism, levels of inequality are nowadays almost as high as at the time of independence. ${ }^{6}$ We would argue that the historically hierarchical structure of these societies has reasserted itself, and that the new leaders-even those who use a "progressive" rhetoric-have simply reverted to the old-fashioned patrimonial state where concentrated political power is used to acquire economic gains. ${ }^{7}$ In short, as in Max Weber's "political capitalism”, political power is a necessary condition for the acquisition of economic power. This tendency might have been exacerbated by the natural wealth of some African countries (Nigeria, Gabon, the Congo, Congo Brazzaville, Angola), where a relatively simple way to wealth was possible: exploit natural resources either independently or by using foreign companies and keep the bulk of the profits in favor of a corrupt elite.

We shall therefore emphasize in the empirical part of the paper the role of the political (democracy) and social (ethnic or religious fragmentation) factors in explaining high levels of inequality in Africa. However, it could be that, in addition, to these factors

the country or its people, but remain an alien body of sojourners, a 'parasite' upon the carcass of its 'host', destined to extract wealth from the country and retiring to consume at home."

\footnotetext{
${ }^{6}$ Luiz (2002, p. 6) writes: “The colonial state's autocratic nature was extended eliminating any competitive pressure and using a system of patronage...to maintain power. State's weakness meant that it resorted to predatory forms of control extracting resources for its own gain rather than employing them in a developmental fashion."

7 "Neo-patrimonialism" is used as a paradigm by a number of writers on Africa (Bratton and van de Walle, 1998; Allen 1999; both quoted in Mkandawire, 2002).
} 
there is still an unidentified "African" component to inequality. The hypothesis will be empirically tested in Sections 3 and 4 of the paper. The previous two sections present some evidence on Africa's current level of inequality and income by contrasting it to Asia and Latin America. They also look at whether similar levels of inequality obtained at the time of independence. In the last Section, we present some reflections on the role of ethnicity and suggestions for further research.

\section{Eyeballing Africa $^{8}$}

Figure 1 compares African with Asian and Latin American countries across two dimensions: inequality (measured by the Gini coefficient) and level of income (measured by the GDP per capita in 1995 \$PPP). The Ginis come from the most recent household surveys conducted (in all three regions) around 1998. In almost all cases, calculations are done from the primary (individual-level) data. All surveys are nationally representative and in all of them inequality statistics are calculated across individuals ranked by their household income or expenditure per capita. ${ }^{9}$ (The full list of countries, and surveys used is given in the Annex 1.)

A comparison of Africa with Asia and Latin America allows us to make several interesting conclusions. First, not surprisingly, Africa is poor and unequal. Average population-weighted GDP per capita (in 1995 \$PPP terms) of African countries included in the sample is around 1,700 which is less than a half of the Asian level, and about a quarter of the Latin American level. The unweighted average GDP per capita ratios are similar. But in addition, Africa is unequal. At Africa's level of income (around \$PPP1,000) there are only a few countries in Asia. But they are uniformly more equal. The difference, easily observable if we compare Panels a and b in Figure 1, amounts to about 10 Gini points. This is a substantial difference: it is equal to the difference in

\footnotetext{
${ }^{8}$ Africa is defined here to include only sub-Saharan Africa.

${ }^{9}$ We had no alternative but to use both income and expenditure as the welfare aggregate, for concentration on either one would have drastically reduced the sample of countries (see the Annex).
} 
inequality between the United States and Austria, and is twice the difference between the US and UK.

But in another way, Africa is also homogeneous: most of it is poor. The standard deviation of countries' GDP per capita is much lower in Africa than in Asia or Latin America (see Table 1). However, the standard deviation of countries' Ginis is greater than in the other two continents. Not surprisingly, inequality in Africa is high in countries where the white minority ruled the longest and where that minority, even if small in percentage terms, was larger than elsewhere and well-entrenched (South Africa, Zimbabwe). ${ }^{10}$ These two countries also have the highest average income levels.

Finally, we notice that there is no apparent pattern in Africa between GDPs per capita and inequality. In effect, there is a very strong clustering of the Gini points in the middle. This is in contrast to Asia, where there is a positive relationship between Gini and income (up to the income level of $\$ 10,000$ where the data are truncated in our Figures) which reminds one of the upward swing of the Kuznets curve. There is also some indication of a similar positive relationship in the Figure for Latin America.

\footnotetext{
${ }^{10}$ Lesotho has the highest inequality of all.
} 
Table 1. Inequality and real income levels in Africa, Asia, and Latin America (around year 1998)

\begin{tabular}{lccc}
\hline & Africa & Asia & $\begin{array}{c}\text { Latin } \\
\text { America }\end{array}$ \\
\hline Inequality & & & \\
\hline Average country Gini & 47.1 & 35.6 & 50.5 \\
Gini standard deviation & 7.9 & 7.7 & 6.2 \\
Minimum Gini & 38 & 23 & 39 \\
& (Madagascar) & (Japan) & (Barbados) \\
Maximum Gini & 66 & 54 & 60 \\
& (Lesotho) & (Papua New & (Colombia) \\
Income in 1995 \$PPP & & Guinea) & \\
\hline $\begin{array}{l}\text { (1) Average GDP per capita } \\
\text { (unweighted) }\end{array}$ & 1670 & 6177 & 5825 \\
(2) Standard deviation GDP per capita & 1958 & 7596 & 3332 \\
(unweighted) & & & \\
Coefficient of variation (2) : (1) & 1.17 & 1.23 & 0.57 \\
$\begin{array}{l}\text { Average GDP per capita (population- } \\
\text { weighted) }\end{array}$ & 1769 & 4015 & 6601 \\
$\begin{array}{l}\text { Number of countries } \\
\text { Population coverage (in percent) }\end{array}$ & & & \\
\hline
\end{tabular}

Note: Latin America includes the Caribbean. 


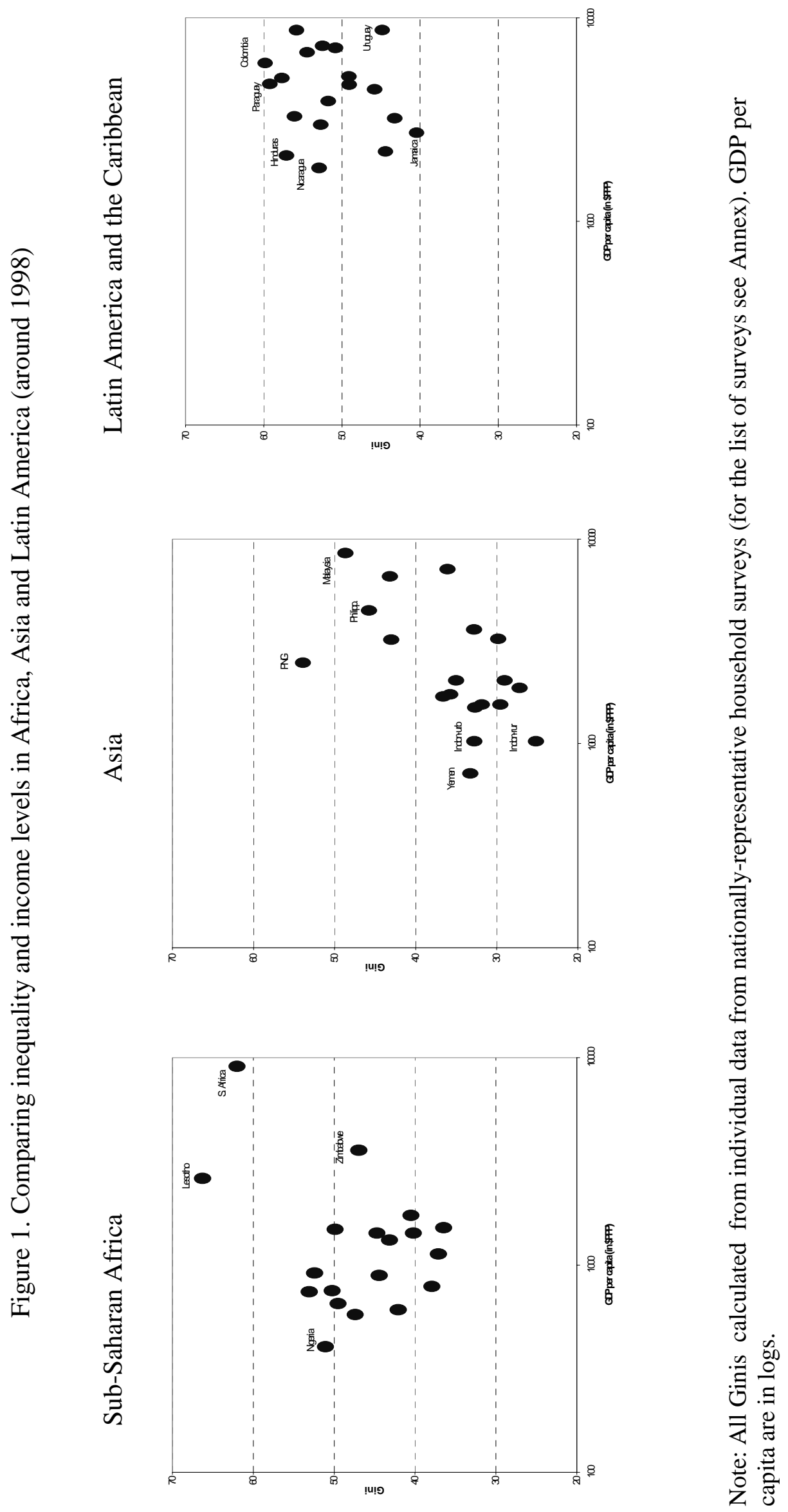

$\infty$ 
3. Was Africa always more unequal?

But if Africa is more unequal now, was it always the case? If we go back to the first available income statistics for Africa, in the 1960's, we indeed find a similar regularity. ${ }^{11}$ As Figure 2 shows, the mean Gini for African countries (calculated from the WIDER data set) in the decade of the 1960's was almost 10 Gini points higher than the mean Gini for the rest of the world. ${ }^{12}$ The difference diminished in 1980's as inequality in Africa declined (and inequality in the rest of the world increased), and then in the 1990's the gap opened up again. Compared to Latin America and the Caribbean, inequality in Africa was always lower but there was a clear "catch-up" in the 1990's. Now, the coverage of the rest of the world and of African countries in particular is uneven (as shown in Table 2). ${ }^{13}$ The sample size and the country composition in Africa change a lot; income and expenditure concepts are mixed. All of that adds tremendous noise to the data displayed in Figure 2.

\footnotetext{
${ }^{11}$ Kuznets (1965, [1954)] thought that income distribution in under-developed countries was getting worse in the 1950's and that the only exception to that tendency was the highly inegalitarian countries where "privileged minorities from metropolitan countries" (p. 169) lost their economic power and left the country at the time of independence.

${ }^{12}$ As for the years before 1960, the WIDER data give only two (person-based) Gini coefficients for Africa. They are for Nigeria and Zambia, both for the year 1959, and are respectively 51 and 48. Kuznets (1965 [1954], p. 155) quotes a UN document that gives income distribution estimates for the early 1950's, for Zimbabwe (Southern Rhodesia) where only 5 percent of the population received 57 percent of total income, Kenya, where 2.9 percent of total population controlled 51 percent of total income, and Zambia (Northern Rhodesia) where the proportions were 1.4 and 45 percent. The same document (National income and its distribution in underdeveloped countries) gives the following ratios for the per capita incomes of nonAfrican and African population: 35 to 1 in Kenya, 58 to 1 in Zambia, and 34 to 1 in Zimbabwe (quoted from Mandel, 1962, vol. 3, p. 144).

${ }^{13}$ Strangely enough, there are very few person-based Ginis in the 1970's. This is the case for the rest of the world too. A greater proportion than usual of the 1970's Ginis included in the WIDER and DeiningerSquire data bases are household-based (distribution of household income across households).
} 
Figure 2.

Mean Gini for African countries, Latin American countries and world without Africa

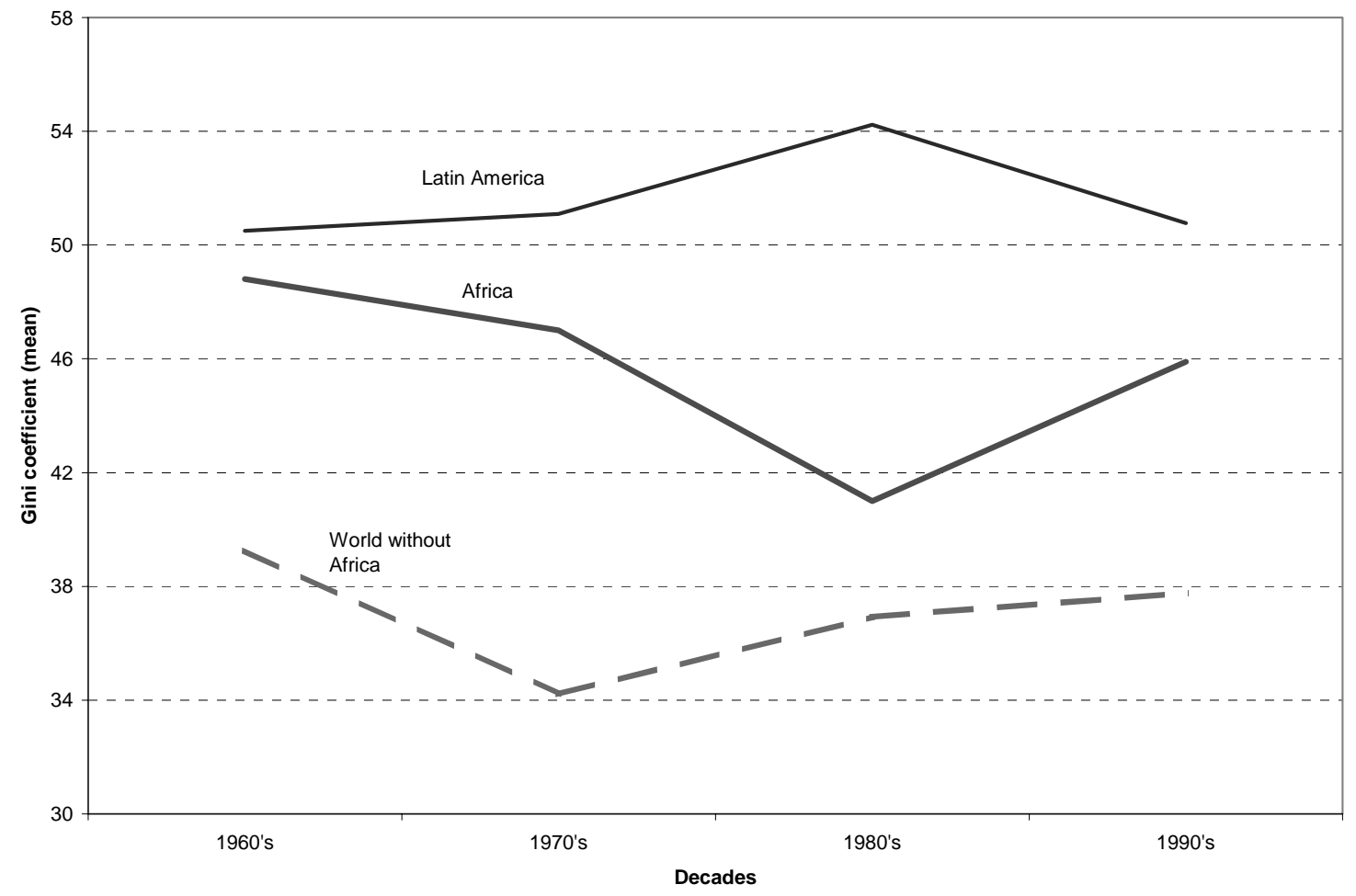

Table 2. Gini coefficients in Africa and the rest of the world, 1960-2000

\begin{tabular}{|l|ccc|ccr|}
\hline & \multicolumn{3}{c|}{ Africa } & \multicolumn{3}{c|}{ Rest of the World } \\
\hline & $\begin{array}{c}\text { Number of } \\
\text { observations }\end{array}$ & Mean & Median & $\begin{array}{c}\text { Number of } \\
\text { observations }\end{array}$ & Mean & Median \\
1960's & 10 & 48.8 & 55 & 48 & 39.3 & 37.5 \\
1970 's & 3 & 47.0 & 44 & 42 & 34.2 & 31.5 \\
1980 's & 13 & 41.0 & 39.6 & 132 & 36.9 & 32.8 \\
1990 's & 42 & 45.9 & 43.9 & 182 & 37.8 & 36.2 \\
\hline
\end{tabular}

Source: Calculated from WIDER data set using only observations where inequality measures are calculated across individuals. 
Table 3. Gini coefficients in selected African countries in the 1980's and 1990's

\begin{tabular}{|l|c|c|c|}
\hline & In the 1980's & In the 1990's & Change \\
\hline Cote d'Ivoire & 36 & 36 & 0 \\
\hline Ghana & $36(2)$ & $34(2)$ & -2 \\
\hline Mauritania & $43(2)$ & $39(2)$ & -4 \\
\hline Mauritius & 40 & 37 & -3 \\
\hline Nigeria & 37 & $43(2)$ & +6 \\
\hline Uganda & 43 & 41 & -2 \\
\hline
\end{tabular}

Note: Number of observations given between brackets (unless there is only one observation).

And indeed the impression of rising Africa inequality in the 1990's is overturned when we keep the composition of the countries unchanged (see Table 3). When we look only at the countries for which have data in both decades, ${ }^{14}$ for four out of six of them, we note that inequality went down. For the other decades, we cannot do even such a fragmentary calculation since there are almost no countries with inequality data in both decades (e.g. 1970's and 1980's).

For only four African countries we have the data on Gini coefficients covering, even if imperfectly, all four decades. They are Tanzania, Nigeria, Madagascar and Zambia (Figure 3). For all of them except Zambia, inequality around the time of independence was not less, and very likely was greater, than is now. Our earlier hypothesis that high inequality in Africa is not a recent phenomenon seems to be confirmed on these few examples for which we have long-run data. Nigeria seems to chart a $\mathbf{U}$ shape type of evolution where inequality by early or mid-eighties was at its low point, and has since increased. Madagascar's inequality appears to be decreasing throughout, and Zambia and Tanzania show no apparent trend.

\footnotetext{
${ }^{14}$ As before, we consider only the statistics calculated across individuals.
} 
Figure 3. Gini coefficients in four African countries, 1960-2000

Tanzania
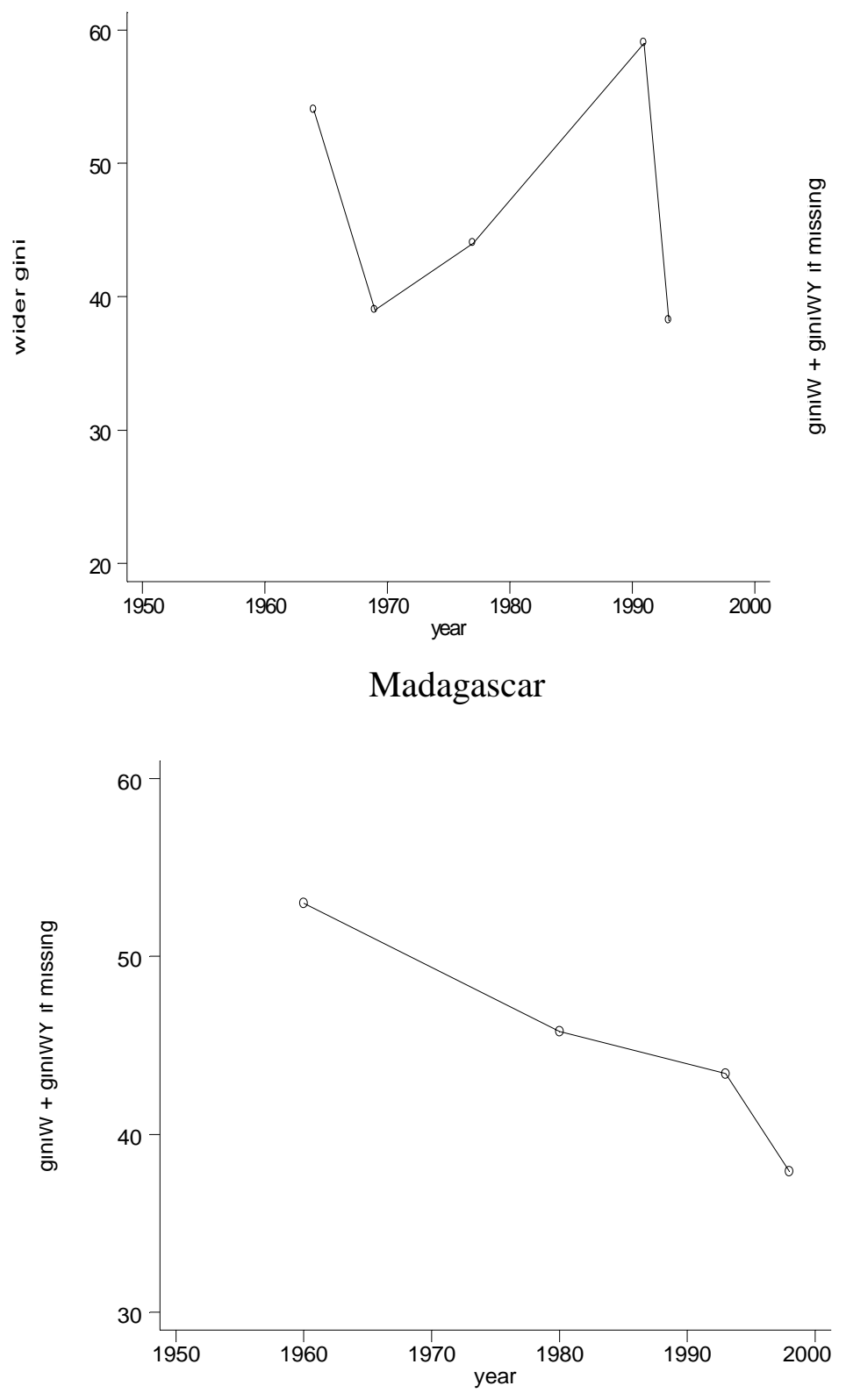

Nigeria

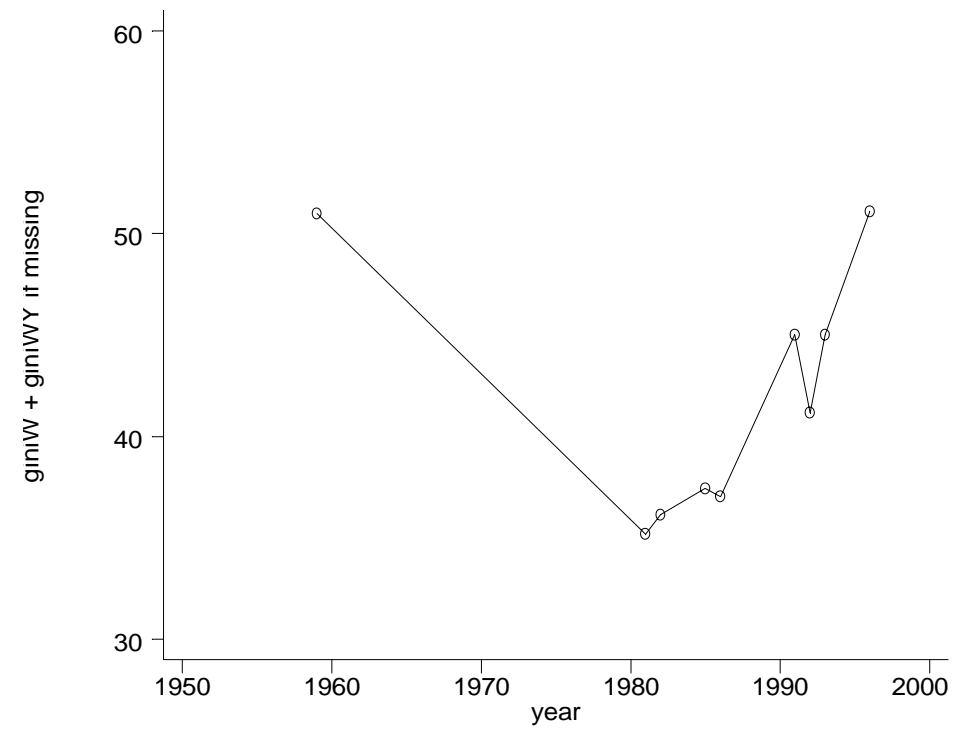

Zambia

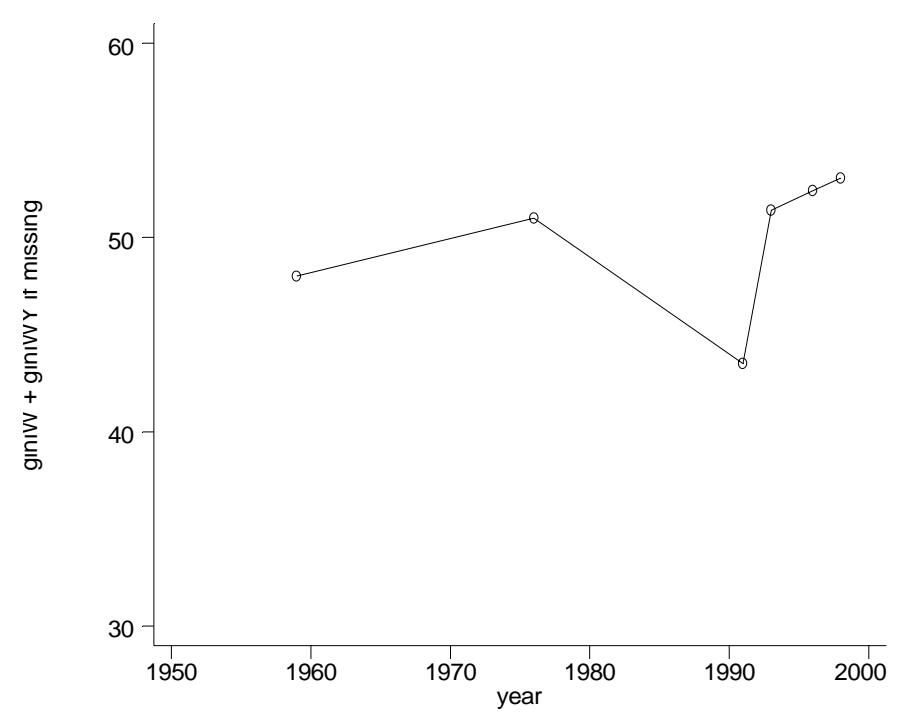


Note that Nigeria's inequality which is U-shaped, is U-shaped in time, not as in the Kuznets hypothesis, plotted against income. In effect, there is no evidence of any Kuznets type relationship for these four countries. Only for Madagascar, whose decline in Gini was accompanied by a decline in real GDP per capita, do we-in that rather paradoxical way_find a positive relationship between income and inequality. ${ }^{15}$ But this would be most difficult to interpret as any evidence whatsoever for the Kuznetsian upswing as the latter depends on (progressive) structural changes in the economy. In a very formal sense one could argue that Madagascar had experienced a reverse, backward change (under-development) that has helped reduce inequality. This interpretation is possible although — when one takes into account that despite income decline over the last 40 years, Madagascar has registered some positive structural changes (improvement in educational achievement, better access to sanitation, lower child mortality) — it is very difficult to interpret these results as having any relevance for the Kuznets hypothesis. Tanzania and Nigeria show a rather meaningless cluster of GDP per capita and Gini values, while for Zambia both GDP per capita and Gini are without a trend (not shown here).

Greater inequality in Africa compared to the rest of the world is illustrated Figure 4 which shows the distribution of the Gini coefficients for all country/years available in the WIDER data base covering the period 1960-2000. African distribution is shifted to the right with the modal Gini in excess of 40 vs. the rest of the world's mode of about 30.

\footnotetext{
${ }^{15}$ Madagascar's GDP per capita declined from a little over \$PPP 1,000 in 1960 to \$PPP 660 in 2000 (all expressed in constant 1995 international dollars).
} 
Figure 4. Distribution of African and rest of the world Ginis, 1960-2000

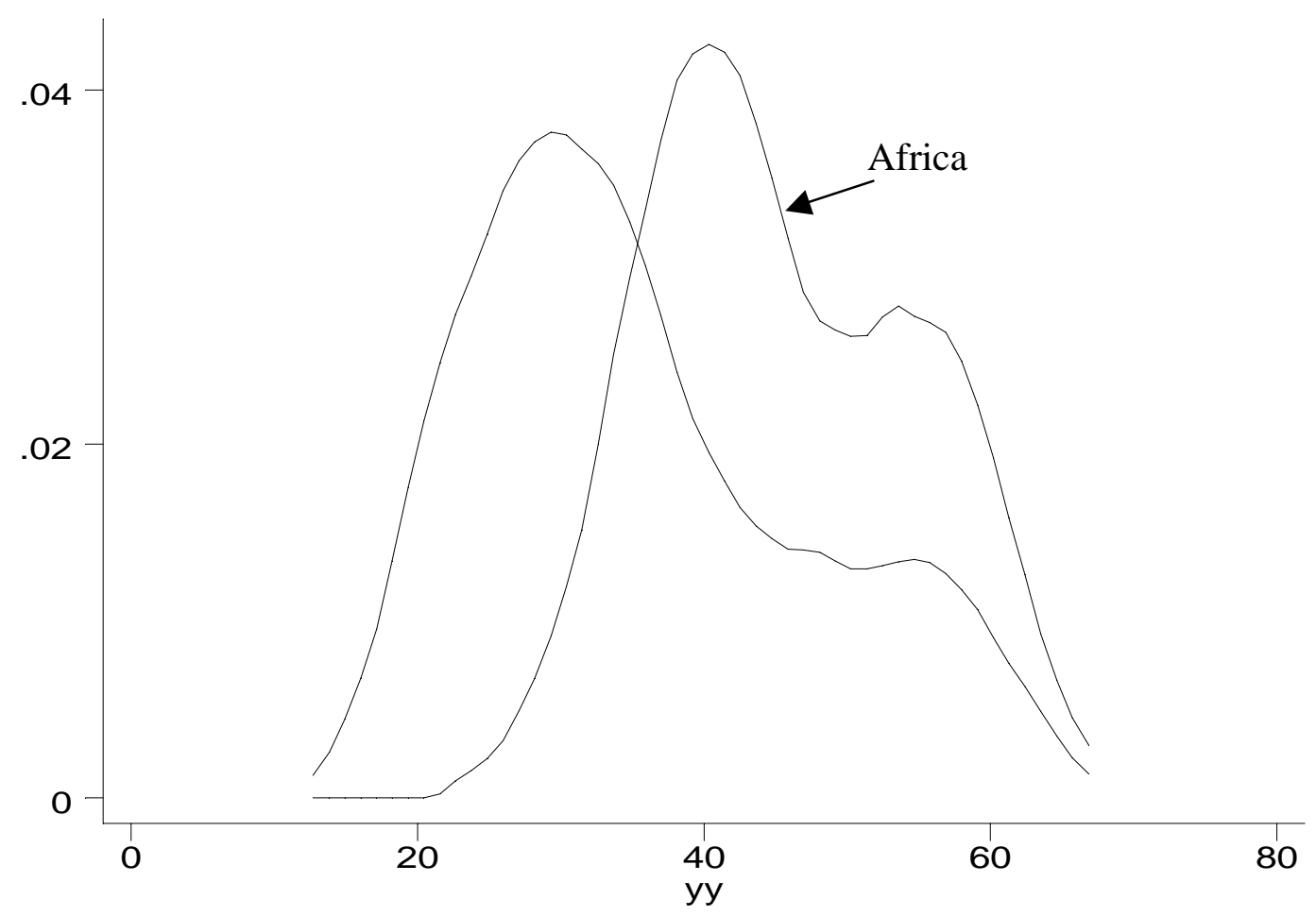

Note: Calculated from the WIDER data base; only person- (not household-) based Ginis.

Thus while, because of lack of data, we cannot say much about the direction of change if inequality in Africa, it seems plausible that high inequality predates independence and that Africa does have higher inequality than the rest of the world. The question of course is Why? For, as we have seen, neither its low income level nor its relatively equal distribution of land seem to predispose Africa for such high levels if inequality. 
4. Econometric analysis: Africa and the rest of the world

Our main interest is to see how well political and social variables are able to explain inequality levels and to check if the determinants of inequality in Africa are different from the rest of the world. Often, they are found to be, and the Africa dummy is claimed to be statistically significant. Higgins and Williamson (1999) in an investigation of the Kuznets hypothesis, find that the Africa dummy is "worth", on average, almost 10 Gini points. Fields (2001, p.67) also reports a significantly greater inequality for subSaharan Africa. Our objective will be to see if we can "explain away" the Africa dummy, that is finding out what the dummy variable really approximates.

In the basic formulation, the explanatory variables include income (to control for the usual Kuznets-type of relationship), political variables, and exogenous social variables. Omitting the country subscript we can write this as (1)

$G i n i_{t}=\beta_{0}+\beta_{1} \ln Y t+\beta_{2}(\ln Y t)^{2}+\beta_{3} P O L I T I C S t+\beta_{4} \mathrm{ETHNO}+\sum_{j=1}^{4} D R_{j t}+e t$

where $\mathrm{t}=$ time (year), $\mathrm{Y}=$ real GDP per capita, POLITICS=various democracy variables, ETHNO=index of ethnolinguistic or religious fragmentation, ${ }^{16}$ and $\mathrm{DR}=$ regional dummies (Africa, Asia, Latin America and the Caribbean, Eastern Europe and the former Soviet Union, with Western Europe, North America and Oceania (WENAO), the omitted category). Regression (1) is an unbalanced panel, with ETHNO and regional dummies being time-invariant controls. The error term is assumed to be orthogonal to the regressors although we do allow (and adjust) for the possibility of endogeneity of several democracy variables. This is a formulation similar to the ones used in Gradstein, Milanovic and Ying (2001) and Li, Squire and Zou (1998). In both cases, level of income and political variables are key. ${ }^{17}$

\footnotetext{
${ }^{16}$ Terms "fractionalization" and "fragmentation" are used interchangeably.

${ }^{17} \mathrm{Li}$, Squire and Zou (1998) use also financial depth variable (M2 divided by GDP) as a proxy for the reverse of capital constraint.
} 
The time period is 1950-2000. The data on Ginis come from WIDER and from world income distribution (WYD) project which collected detailed household survey data for more than one hundred countries covering the period from the mid-1980's to the late 1990's. ${ }^{18}$ We have a total of 1067 Gini observations: 882 come from WIDER, the rest from WYD project. ${ }^{19}$ The data on GDP per capita come mostly from the World Bank SIMA database. However, they are complemented by other sources, most notably from countries' own statistical yearbooks and this particularly so for the countries that were not independent during the entire $1950-2000$ period. ${ }^{20}$

In the simplest formulation 1 (table 4, column 1), we use only one political variable: the three-year average lagged Democracy from PolityIV database (version June 2000). The Democracy variable is defined as "general openness of political institutions" and it ranges from 0 to 10 (higher values denote greater democracy). For ETHNO, we use an index of ethnolinguistic fragmentation. ${ }^{21}$ The major interest of regressions like (1) lies in isolating the Africa-specific effect, that is testing whether African data behave differently than those from the rest of the world rather than in estimating the exact parameters of (1). We do this first by the inclusion of regional dummies. ${ }^{22}$ The role of

\footnotetext{
${ }^{18}$ More on this in Milanovic (2002).

${ }^{19}$ The data are of all kinds: recipients are either households or individuals, welfare aggregate is income or expenditures, the data are gross of taxes or net. As has become standard, we adjust for these differences in definitions by using dummies. It is a necessary adjustment, but not the one that can be enthusiastically endorsed. As Ivaschenko (2002) rightly observes, in many instances in transition countries, the bias of one definition over another is neither constant, nor is even the direction of the bias always the same.

${ }^{20}$ For more information on GDP per capita series see Milanovic (2003).

${ }^{21}$ The index measures the probability of two random individuals from a given country belonging to the same ethnic group. The index obviously ranges from 0 to 1 . Its formula is $1-\sum\left(\frac{n_{i}}{N}\right)^{2}$ where $\mathrm{n}_{\mathrm{i}}=$ size of $i$-th group, N=total population. We use here the index calculated by Annett (2000) from the World Christian Encyclopedia (Barrett, 1982). The advantage of this index compared to the more commonly used index derived from the Soviet sources (see Mauro, 1995; Easterly and Levine, 1997) is a much more detailed ethnic grouping, more recent data, and broader country coverage (150 countries). The data were kindly supplied by Anthony Annett.

${ }^{22}$ For the reasons just explained, we keep regional dummies in all the regressions. Annett (2001, p. 17) gives an additional reason. When in his regression with government consumption as the dependent
} 
the three-year lagged average for the Democracy variable is to avoid endogeneity (the contemporaneous effect of inequality on democracy) and more substantively, to allow for the fact that democracy is unlikely to affect inequality immediately. The results show that, with other factors being equal, countries in Africa would have a Gini coefficient about 10.3 points higher than WENAO countries (the omitted category). This comes on top of controlling for ethnic fractionalization which is the highest in Africa ${ }^{23}$ and which also contributes to inequality. The Africa dummy is significant but smaller than the Latin America dummy by more than 2 Gini points. Test of equality of the two dummies however is not rejected. Thus while Africa seems to display greater inequality compared to the rest of the world, that "rest of the world" does not include Latin America and the Caribbean.

In formulation 2, we introduce more controls for the political system: a dummy variable for the type of political system (presidential system, assembly-elected president, and parliamentary system), and an index of government cohesiveness. Both variables come from the Database of Political Institutions (DPI) developed by Beck et al. (2000). ${ }^{24}$ Unlike Democracy, the System variable does not measure level of democracy but simply addresses the issue of where, in a given setting, the political power lies: in a president, in an assembly-elected president, ${ }^{25}$ or in a prime minister that depends on parliamentary majority (regardless of how that majority is obtained-whether by

variable, regional dummies were not included, ethnic fractionalization variable was insignificant. Once the regional dummies are included as controls, fractionalization becomes highly significant. This is explained by strong regional patterns of government consumption. The same seems a priori plausible here too as inequality does display strong regional features.

${ }^{23}$ The unweighted average of the index is 0.68 in Africa (0.73 in sub-Saharan Africa), 0.52 in Asia, 0.45 in Latin America, and 0.26 in WENAO, and 0.2 in Eastern Europe/FSU where the index is available for only four countries (Hungary, Romania, Bulgaria and Poland).

\footnotetext{
${ }^{24}$ We used the most recent (March 2003) version of DPI; it is available at http://www.worldbank.org/research/bios/pkeefer.htm.

${ }^{25}$ These are systems where the chief executive is elected by parliaments but cannot be easily dismissed, that is the chief executive does not depend on parliamentary majority to remain in office. This is a difference between say, Egypt where the president is elected by the Parliament and can hardly be dismissed, and the UK where the Prime Minister cannot survive without Parliamentary majority. For the year 1997, countries with such a system are China, Egypt, Guyana, Indonesia, Laos, South Africa, Vietnam, Yemen. Before the transition, many Communist countries fell in the same category.
} 
competitive elections or not). ${ }^{26} \mathrm{We}$ also use Herfindahl Index of Government

Concentration from the Database of Political Institutions. The variable measures political cohesiveness of government with lower values indicating more fragmented or less cohesive government (e.g. a coalition government with many parties). Unfortunately, since the DPI data are available only for the period 1975-2000 we lose a significant number of observations. The coefficients change too. Ethnic fractionalization becomes much more important (jumping from 2.7 to 4.3 Gini points) and despite that, so does the Africa dummy which now amounts to more than 13.5 Gini points, a value higher than that of the LAC dummy. The hypothesis of equality of the two dummies is easily accepted. In formulation $\mathbf{3}$, we drop the average three-year lagged Democracy variable and instrument contemporaneous Democracy by its lagged value. The results are unchanged. In formulation 4, we replace Democracy variable with another variable that also reflects the level of democracy: Party competitiveness similarly derived from PolityIV database and averaged over three years. Party competitiveness measures the "extent to which non-elites are able to access institutional structures for political expression", and ranges from 0 to 5 (definitions taken from the code book of Polity database by Jaggers, 1996). ${ }^{27}$ The two variables are strongly correlated (above 0.9) ${ }^{28}$ and the coefficients on the fractionalization variable and the Africa dummy are practically unchanged. Party competitiveness performs much better than Democracy and is significant and negative. We thus keep Party competitiveness in all other formulations.

We then move to testing whether the slopes (in addition to the intercept) may also be different for African countries. We are mostly interested in how democracy and ethnolinguistic fractionalization affect inequality in Africa compared to the rest of the world. The first is clearly a political variable; the second may be thought of one (in the

\footnotetext{
${ }^{26}$ DPI uses a set of clear rules to distinguish between political systems, such as presidential veto power, presidential appointment of ministers and dissolution of the parliament. Thus, the French system is classified as parliamentary, because the Prime Minister depends only on parliamentary majority and not on president's will, and the Russian system as presidential since the Prime Minister is proposed by the President while the Duma can only reject him.

${ }^{27}$ Available on the Internet at ftp://isere.colorado.edu/pub/datasets/polity3/polity3.codebook.

${ }^{28}$ They are, however, not as strongly correlated in Africa. The correlation coefficient is 0.79 .
} 
sense that it proxies for the way political pressure groups are formed). We interact both of them with the Africa dummy in formulation 5. Neither variable has a different effect in Africa compared to the rest of the world although the Africa dummy declines and (possibly because of collinearity) ceases to be significant.

We move next to checking whether dependence on commodity production and exports, where rents are presumably more easily appropriated, may account for high inequality in Africa. Easterly (2002) argues that commodity endowments predict well middle-class share, that is, inequality. Birdsall and Hamoudi (2002) have created a variable which, based on the export data for the period 1980-84, divides the countries into highly commodity-dependent, medium commodity dependent and least commodity dependent. ${ }^{29}$ The results are given in formulation 6. Both commodity-dependence dummies are significant but with different signs: being medium commodity-dependent country contributes to inequality, being highly commodity-dependent reduces inequality (compared to the omitted category of least commodity dependent). ${ }^{30}$ The latter is a rather unexpected result contradicting Easterly (2002) and the literature on the link between commodity dependence and inequality. It may be explained by the fact that other variables, specifically regional dummies, included here have swept away some of the commodity dependence effect, or that the effect is non-existent or not robust enough. ${ }^{31}$ Yet the important thing for us is that the interaction between ethnic fractionalization and Africa dummy becomes strongly significant, while the Africa dummy is not. ${ }^{32}$ We shall therefore keep formulation 6 and contrast it with others.

\footnotetext{
${ }^{29}$ To be highly commodity dependent, a country's share of primary commodity and natural resource exports in total exports needs to exceed a cut-off point of approximately 90 percent in four out of five years, 1980-84 (the exact annual cut-off points are explained in Birdsall and Hamoudi, 2002, p. 11). If a country's share is below this cut-off point in all years, it is classified as "least commodity dependent." Those in-between are classified as medium commodity dependent. The data were kindly provided by Amar Hamoudi.

${ }^{30}$ Note that the "overall" omitted category is a WENAO country with a presidential system and low commodity-dependence. The United States is one such country.

${ }^{31}$ The average Gini of highly commodity dependent countries (43.6) is higher than that of least commodity dependent (37.6) but not that of medium commodity dependent (50.6).

${ }^{32}$ If we replace interaction between fractionalization and the Africa dummy with ethnic fractionalization squared-arguing that there may, in general, be convexity in the relationship between ethnic
} 
In formulation 7, we keep the same variables as in $\mathbf{6}$ except that we replace ethnolinguistic fractionalization with religious fractionalization to check whether the two fractionalizations have the same effect. Religious fractionalization variable is calculated from the same source as ethnic fractionalization (see footnote 21 above). In most countries, ethnic fractionalization is greater than the religious. ${ }^{33}$ The two fragmentation variables are barely positively correlated in the rest of the world although they are somewhat more correlated in Africa (Table 5).

Table 5. Ethnolinguistic and religious fractionalization in Africa and rest of the world

\begin{tabular}{lcc}
\hline & Africa & Rest of the world \\
\hline Mean(median) ethnic fractionalization & $0.73(0.79)$ & $0.39(0.39)$ \\
Mean(median) religious fractionalization & $0.56(0.62)$ & $0.31(0.25)$ \\
Correlation between the two & 0.23 & 0.1 \\
fractionalizations & & \\
Standard deviation of ethnic fract. & 0.19 & 0.24 \\
Standard deviation of religious fract. & 0.20 & 0.24 \\
\hline
\end{tabular}

Note: Maximum fractionalization 1: likelihood of two random individuals belonging to two different group is then 100 percent.

Source: Annett (2000).

Unlike ethnic fractionalization, religious fractionalization alone has no significant effect, and the interaction of religious fractionalization and the Africa dummy, turns out to be similarly not significant. The Africa-specific intercept becomes greater than zero. So in the other formulations, we return to using ethnic rather than religious fractionalization.

It would seem that most of Africa's "exceptionalism" (high inequality) is not accounted for by a greater ethnolinguistic fractionalization as such, but by stronger

fractionalization and inequality (with higher levels of fractionalization having an additional positive effect), the squared variable is indeed significant but so is still the Africa dummy. Similarly, interaction between ethnic fractionalization and commodity dependence shows a significant positive effect for high commodity-dependent countries, but does not make the Africa dummy variable insignificant. (Results of both regressions available on request.)

${ }^{33}$ This is not surprising because the number of ethnicities in the world surpasses by much the number of religions. 
inequality-increasing effect that ethnic fractionalization has on inequality in Africa compared to the rest of the world. The reasons why ethnic fractionalization would contribute to inequality and why it would do even more so in the African context are not clear. We may speculate that ethnic fragmentation may contribute to inequality in a similar way in which it impedes growth (as argued by Easterly and Levine, 1997, p. 1232-3): by leading to a political fight over the spoils between the different ethnic groups that alter in the government. In that sense, the "spoils economy" will not only retard growth but may lead to high inequality in the distribution of income. That scenario may also be viewed as an illustration of simultaneous determination of inequality and growth — a point which has plagued empirical estimates of the relationship between the two (see Dollar and Kraay much quoted 2002 paper).

But could it be that when we interact democracy and fractionalization variables with the Africa dummy, we wrongly attribute these effects to something specifically "African" when the issue could be that it is low levels of GDP that are to blame? In other words, ethnic fragmentation may have more deleterious effects on inequality in relatively poor settings whether they are in Africa or not. In formulation 8, we interact Party competitiveness and Ethnic fractionalization with (ln of) GDP per capita. Both interactions are significant. The results are not unexpected: as countries become richer, ethnic fractionalization has less of a deleterious impact on inequality, and democracy has a more powerful favorable effect (inequality-reducing). However the new formulation does no do away with the Africa effect: the Africa dummy remains highly significant. The important result for us is that the Africa dummy when interacted with democracy and ethnic fractionalization (that is, formulation 6) performs differently from GDP per capita, and thus cannot be simply replaced by the latter. There are apparently some "African"not GDP related—features that make fragmentation particularly conducive to high inequality. This is confirmed by formulation 9 where we keep everything as in $\mathbf{8}$, but add interaction between ethnolinguistic fractionalization and the Africa dummy. In this direct test of whether African inequality is higher because the continent is poor or because it is "Africa" (whatever it may be), the latter hypothesis performs better. The interaction 
between ethnicity and Africa is significant, while the one between ethnicity and income is not. The Africa dummy in turn ceases to be significant.

Another alternative could be that the fractionalization variable adds so much to inequality in Africa because Africa is not sufficiently democratic. One can hypothesize that religious or ethnic fragmentation is less of a social problem, and less likely to lead to high inequality in more democratic settings. In formulation 10, we therefore keep formulation 6 and add interaction between ethnic fragmentation and democracy. The new variable is highly significant (at higher levels of democracy ethnic fractionalization's effect on inequality is muted), but so is the Africa dummy.

Finally, yet another alternative could be that being a commodity-dependent producer in Africa makes inequality higher. We test this by interacting commodity-dependence variables with the Africa dummy (formulation 11). The interaction terms are not significant, so we have to reject this hypothesis too.

Thus, the formulation 6 seems to be our preferred formulation. We test it further by replacing commodity dependence by "point source" producer countries. It has been recently argued (Murshed 2002, Woolcock, Pritchett and Isham, 2001) that it is the specific type of commodity producers, namely the "point source" producers (and exporters) who are likely to experience extensive rent-seeking, high corruption, political instability, and thus, one could surmise, high inequality. This is based on the view that natural resources that are found in one place like oil, diamonds, and gold can be easily taken control of by a corrupt group that can use the proceeds for personal enrichment or to prosecute a war. ${ }^{34}$ In formulation 12, we create a dummy variable for all countries which, according to a classification in Murshed (2002), were "point exporters" in the mid-1980's. The results are fairly unambiguous: being a "point exporter" has no impact

\footnotetext{
${ }^{34}$ More diffused natural resources are presumably more difficult to control, e.g. coffee, wheat etc. depend on the work of thousands of farmers who cannot all be spoiled of their output.
} 
on inequality. ${ }^{35}$ However, variables that were significant before in formulation $\mathbf{6}$, including the interaction between ethnic fragmentation and the Africa dummy cease to be so, while others (party competitiveness and assembly-elected president), turn significant.

It can be also argued that inequality in Africa is high because of lack of withincountry integration and low population density: bad transportation system and large distances between the settlements hinder trade and migration from poorer to richer areas. We test for this by including population density (number of people per square kilometer) in formulation 13. The variable is significant, and has the expected sign (negative). It does not affect however our earlier results from formulation $6 .{ }^{36}$

We conclude that the regressions show that democracy (in its several formulations) has an inequality-reducing effect only at relatively high income levels, and that the type of political system matters with the presidential system being consistently the most unequal. Ethnic fractionalization is throughout associated with greater inequality, but its importance diminishes at higher levels of income and democracy. Not surprisingly, ethnic fractionalization is much less of a "bad" if countries are rich and democratic. It might then seem that the "African problem" is not ethnic fractionalization per se, but rather low income and democracy that "allow" ethnic fractionalization to play a negative role (in increasing inequality).

However, this is not the case because adjusting for all of these effects still leaves an unexplained Africa dummy. The latter is eliminated only when it is interacted with the ethnic fractionalization variable, implying that there may be unobserved, specifically African, features that seem to operate through ethnic fractionalization. While ethnic diversity is everywhere associated with greater inequality, there is an additional effect in Africa which we capture through the slope coefficient (interaction between the Africa

\footnotetext{
${ }^{35}$ However, if we omit regional (Africa, Asia etc) dummies, the point-source exporter variable becomes significant. This suggest that its significance is due to the omitted variable bias, that is, once we control for regionally-specific effects, the point-source variable loses its relevance.

${ }^{36}$ When we interact Africa dummy and population density, the variable is not significant implying that low density does not have a different impact in Africa compared to the rest of the world.
} 
dummy and ethnic fractionalization). This pinpoints to a proximate cause of greater inequality in Africa, but it does not provide a clear mechanism, nor an explanation about the way this proximate cause affects inequality. A reasonable hypothesis is, of course, that it does through the same mechanism which is speculated to have been behind Africa's "growth tragedy" as argued by Easterly and Levine (1997). We shall return to this in Conclusions.

It is also noticeable that in almost all formulations, regional dummies (except for Asia) are statistically significant. As expected, Eastern Europe/FSU show lower inequality than the West (omitted category) although this is largely offset by the evolution during the transition years (a highly significant positive dummy). Latin America, as discussed before, displays significantly greater inequality than Western countries but not greater than Africa as the hypothesis of the difference between the two regional dummies is rejected in all formulations.

After this analysis where we have "confronted" Africa to the rest of the world, we move to an empirical analysis of inequality within Africa. While finding out whether (and why) Africa is different from the rest of the world is important, additional insight may be gained by looking at individual African countries to see what makes them similar or different from each other. Moreover, the parameter homogeneity can in the "Africa only" case be assumed to be greater and thus our estimates more precise. Our attention will be directed particularly to the role of ethnic fractionalization: if ethnic fractionalization has more negative effects in Africa (compared to the rest of the world), we would expect that this effect would be present in the African context too: namely, that higher ethnic fractionalization will be associated with greater inequality within Africa as well. 


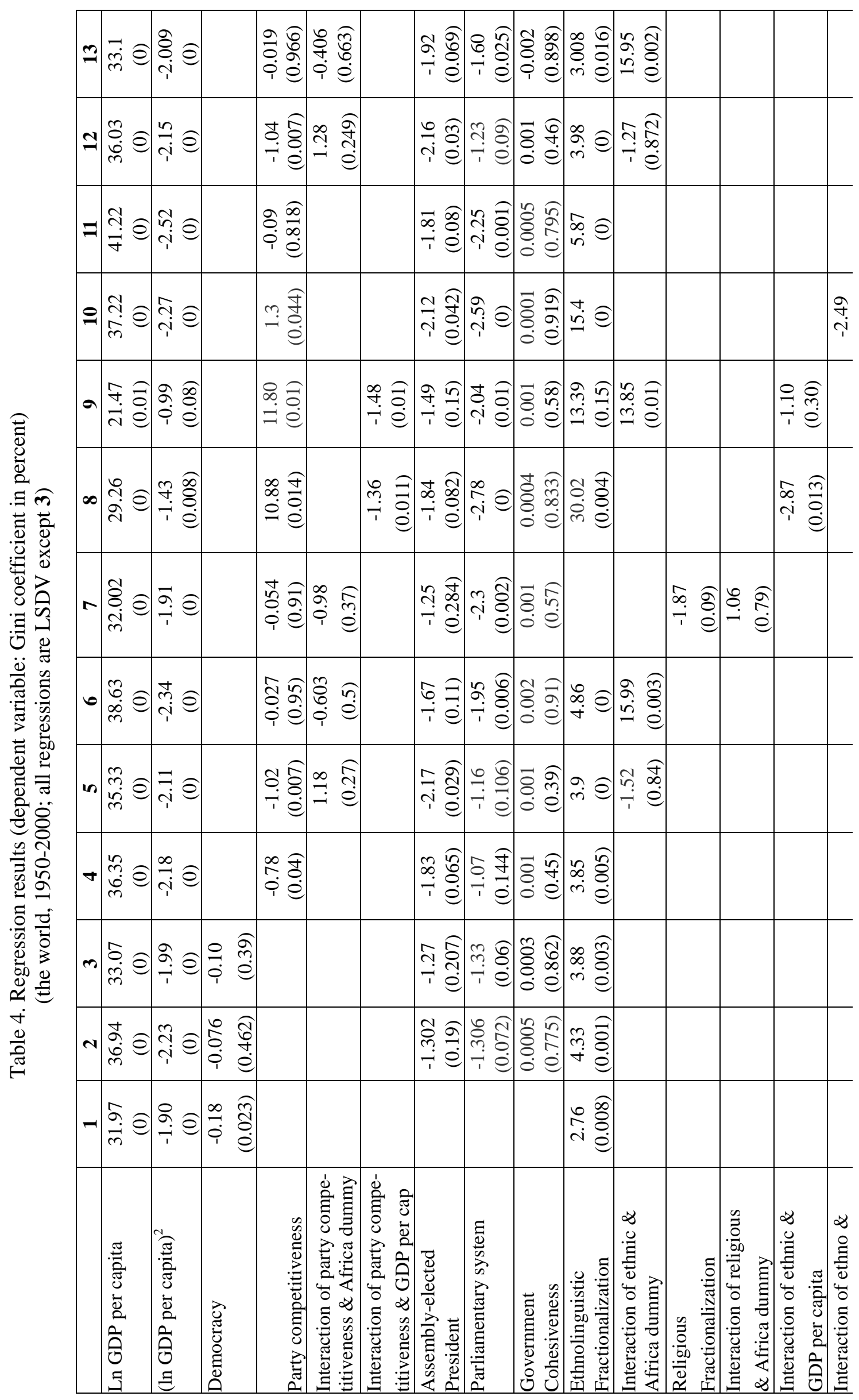




\begin{tabular}{|c|c|c|c|c|c|c|c|c|c|c|c|c|}
\hline 9 & $\vec{n}$ & $=e^{d}$ & i. & $\stackrel{n}{=}$ & 6 & 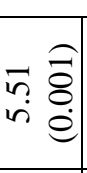 & $\operatorname{lol}$ & 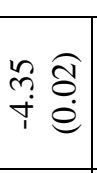 & & & & 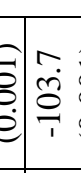 \\
\hline$y$ & 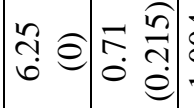 & & bु & $\stackrel{+}{=}$ & 管 & $\underset{\infty}{+} \hat{a}$ & & & & & & \\
\hline 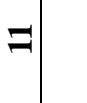 & & $\exists$ & $\mid \infty$ & & 它 & is & & & 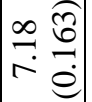 & רִ & & \\
\hline$\stackrel{8}{e}$ & & & 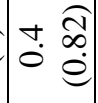 & $c$ & 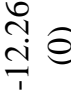 & 命 & & & & & & \\
\hline & 으 & $\underline{c}$ & 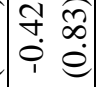 & స్ & $\frac{\infty}{1} \widehat{a}$ & $\frac{ \pm}{\infty} a$ & 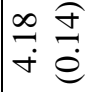 & 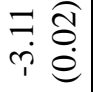 & & & & \\
\hline & 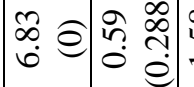 & $n$ & 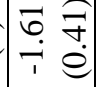 & $\bar{\infty}, 0$ & 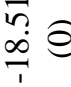 & $\frac{m}{\infty} a$ & 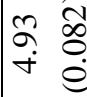 & 它 & & & & \\
\hline & & & 索常 & ָָ & 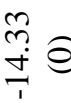 & $\stackrel{0}{0}$ & & 用 & & & & \\
\hline & & 0 & : & î̀ & 列 & 它 & 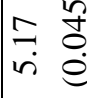 & 象 & & & & \\
\hline 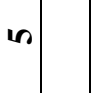 & $8=$ & 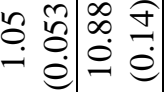 & 㲅 & $\underset{H}{+} 0$ & 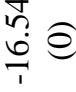 & $\vec{\infty} \underset{\infty}{0} \hat{\theta}$ & & & & & & \\
\hline & $N=$ & & 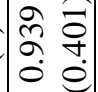 & ते & قِ & 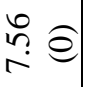 & & & & & & \\
\hline & $\overrightarrow{\vec{b}} \widehat{\varrho} \widehat{\varrho}$ & & $\stackrel{\infty}{\infty}$ & & 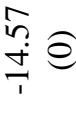 & రై & & & & & & \\
\hline & $\hat{\hat{\omega}}$ & 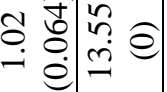 & & 声 & 票 & $\overbrace{0}^{\infty} \widehat{c}$ & & & & & & \\
\hline & & & $\mid$ & 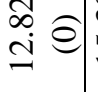 & 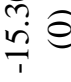 & 京 & & & & & & \\
\hline in & 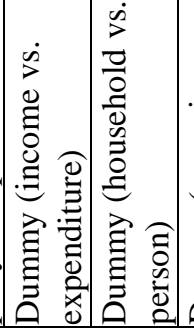 & 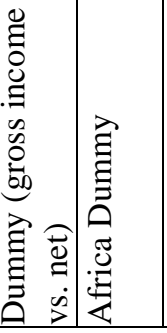 & 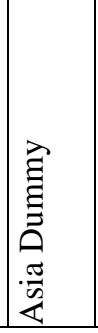 & 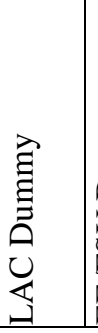 & 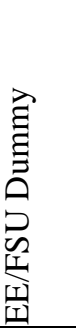 & 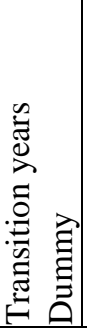 & 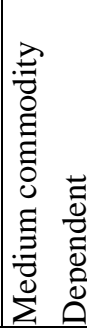 & 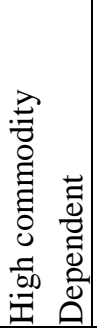 & 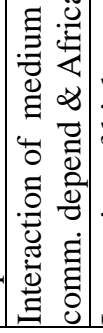 & 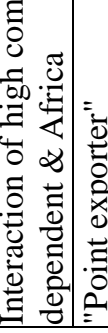 & & 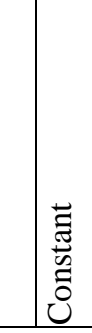 \\
\hline
\end{tabular}




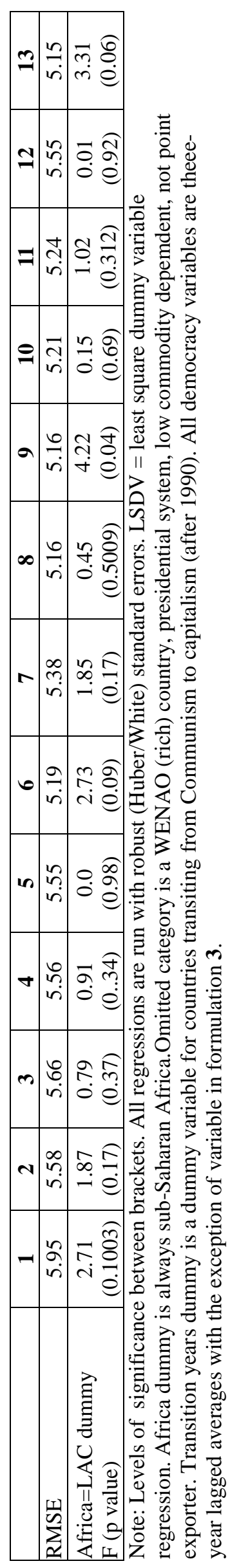




\section{Econometric analysis: inequality in African countries only}

A standard approach in the presence of suspected parameter heterogeneity is to splice the sample into more homogeneous groups. This is what we are doing here by focusing on African countries alone. Note, first, that the problem of too few observations makes a fixed-effects regression rather pointless. There are on average less than three observations (Ginis) per country for the entire 40-year period. There are only 14 countries with more than 3 observations (see Annex 2). We thus run pooled regressions as shown in Table 6.

We begin with very similar formulations as previously for the whole world. Formulation 1 shows that the results for Africa alone are much weaker. GDP per capita does not play any role-not surprising in view of the fact noted in Figure 1 above that in Africa inequality and GDP per capita seem to be orthogonal. Likewise, Party competitiveness and Ethnic fractionalization are unimportant. The interesting novelty is that systems with assembly-elected president seem to be associated with higher inequality compared to the omitted category of presidential system. This is exactly the opposite of what we found for the world as a whole. One must not read too much in these findings however because the sample size is too small: a huge majority of African countries have presidential system. The only country in the sample with the assemblyelected president is South Africa (since 1990) which then of course "assigns" large inequality-enhancing effect to that system. ${ }^{37}$ Thus in the rest analysis we combine the assembly-elected presidential system with direct presidential system (as the omitted category).

In Formulation 2, we run the same regression as $\mathbf{1}$ instrumenting for contemporaneous Party competitiveness by its lagged value. None of the variables is

\footnotetext{
${ }^{37}$ The only countries with a parliamentary system (and Gini observations) are Botswana, Mauritius and Zimbabwe (throughout the whole period), Ethiopia (since 1996) and Lesotho (since 1994). All other countries save South Africa and Niger (in one year) have presidential system.
} 
significant. ${ }^{38}$ In formulation 3, where we interact Party competitiveness and GDP per capita, there is again no significance at conventional statistical levels. In the next formulation 4, we add the "point source" variable, and the results practically reproduce these from Formulation 3. In formulation $\mathbf{5}$ where we replace the "point" producers by the commodity dependence variable we begin to get some interesting results and $\mathrm{R}^{2}$ almost doubles. The importance of ethnic fractionalization shoots up to become highly significant. Having parliamentary system is also highly significant and strongly proinequality (adding some 10.3 Gini points compared to the presidential system). And being medium-commodity dependent, as we previously found for the world, is bad for equality. ${ }^{39}$

Would dominant religion (Catholic, Muslim, African traditional etc.) make a difference to inequality? ${ }^{40}$ We test this in formulation 6 . Table 7 shows the distribution of African countries according to the dominant religion as well as the same distribution across African countries (data points) in our sample. The two distributions are quite similar. Countries without a dominant religion (that is, mixed religion countries) are the most frequent in Africa. They account for about a third of all African countries, followed by the (new) Christian, ${ }^{41}$ and the mixture of Christian and traditional African religions, and then by Muslim countries (1 out 5 sub-Saharan African countries is dominantly Muslim).

\footnotetext{
${ }^{38}$ The same is true if we use a fixed-effect (countries) formulation of equation 1. A severe lack of intertemporal observations for the same country should be kept in mind: the average number of data points is 2.7 per country (out of maximum of 41 data points per country).

${ }^{39}$ On a cautious note, there are only four medium-commodity dependent countries in Africa (Gabon, Guinea Bissau, Malawi and Niger) with a grand total of 11 Gini observations.

${ }^{40}$ The rule used in deciding what is a dominant religion in a given country was that at least 40 percent of the population had to have the same religion, with the second most numerous religion not exceeding 25 percent of the population. In cases when two or even three religions have similar number of adherents, a single dominant religion could not be defined. If two religions (e.g. Christian and traditional African) claim about the same number of votaries, we create a hyphenated category. If however there are more than two religions with approximately the same number of people (as in Nigeria, Burkina Faso, Cote d'Ivoire etc.), the country is assigned in the group with no dominant religion. For details see Gradstein, Milanovic and Ying (2001).

${ }^{41}$ Somewhat overrepresented in our sample. The prefix "new" (Christian) is simply added to indicate that these countries have adopted Christianity relatively recently (compared to the rest of the world).
} 
The results are interesting. The societies without a dominant religion are found to be significantly less unequal. For others, religion does not matter. ${ }^{42}$ Ethnolinguistic fractionalization remains highly significant such that each 10 percent increase in fractionalization raises inequality by 3.3 Gini points. Contrary to what we found for the world as a whole, this impact is not diminished by higher income level (results not shown here). ${ }^{43}$ When superimposed on ethnic cleavages there is also religious fragmentation inequality is curiously less. Is it because in that case a modus vivendi must be found unless the country explodes in a civil war and thus is not even included in the sample? ${ }^{44}$ Parliamentary system remains pro-inequality.

But would the effect of ethnic fractionalization be reduced if country becomes more democratic? We have seen this to be true for the world as a whole even if this still did not explain away the Africa effect. We test this using formulation 7. And indeed, within African context, greater democratization (unlike greater income) renders the proinequality effect of ethnic fractionalization insignificant even if democracy alone does not reduce inequality. This is potentially an important finding as it suggests an indirect mechanism whereby democracy leads both to lower inequality ${ }^{45}$ and (perhaps) to a change away from politics based on ethnic mobilization. ${ }^{46}$

\footnotetext{
42 The dummies for Christian Orthodox and Buddhist/Hindu are actually country dummies for Ethiopia and Mauritius since they are the only countries with these religions in Africa.

${ }^{43}$ Does ethnic fractionalization makes inequality worse in conditions of point-exports and commodity dependence? No, we interact both variables with the fractionalization variable and none of the interactions and none of the variables is significant (regressions available on request). It seems therefore that the effect of ethnic fractionalization can be separated from the fortuitous presence or not of mineral deposits or wealth in commodities.

44 There are no household surveys while countries are undergoing civil wars.

${ }^{45}$ By nullifying the pro-inequality effect of ethnic fractionalization.

${ }^{46}$ On a related topic, namely why democracy in Africa might facilitate economic reform see van de Walle (1994).
} 
Table 6. Regression results for African countries alone (dependent variable: Gini coefficient in percent; pooled regressions)

\begin{tabular}{|c|c|c|c|c|c|c|c|c|}
\hline Formulations & 1 & 2 & 3 & 4 & 5 & 6 & 7 & 8 \\
\hline Ln GDP per capita & $\begin{array}{c}6.85 \\
(0.833) \\
\end{array}$ & $\begin{array}{l}-4.15 \\
(0.887)\end{array}$ & $\begin{array}{c}3.55 \\
(0.895) \\
\end{array}$ & $\begin{array}{l}16.17 \\
(0.578 \\
\end{array}$ & $\begin{array}{l}0.129 \\
(0.97)\end{array}$ & $\begin{array}{l}-52.74 \\
(0.27) \\
\end{array}$ & $\begin{array}{l}-66.52 \\
(0.20) \\
\end{array}$ & $\begin{array}{l}-64.23 \\
(0.22)\end{array}$ \\
\hline$\left(\right.$ ln GDP per capita) ${ }^{2}$ & $\begin{array}{l}-0.683 \\
(0.753) \\
\end{array}$ & $\begin{array}{c}0.325 \\
(0.869) \\
\end{array}$ & $\begin{array}{l}-0.101 \\
(0.952)\end{array}$ & $\begin{array}{l}-1.18 \\
(0.54\end{array}$ & $\begin{array}{l}-0.04 \\
(0.98)\end{array}$ & $\begin{array}{c}3.47 \\
(0.27)\end{array}$ & $\begin{array}{c}4.44 \\
(0.19)\end{array}$ & $\begin{array}{c}4.28 \\
(0.21) \\
\end{array}$ \\
\hline Party competitiveness & $\begin{array}{c}6.64 \\
(0.298)\end{array}$ & $\begin{array}{l}-0.302 \\
(0.793)\end{array}$ & $\begin{array}{c}9.02 \\
(0.287)\end{array}$ & $\begin{array}{l}-1.28 \\
(0.212)\end{array}$ & $\begin{array}{l}-1.34 \\
(0.15)\end{array}$ & $\begin{array}{l}-1.73 \\
(0.17)\end{array}$ & $\begin{array}{l}-21.57 \\
(0.08)\end{array}$ & $\begin{array}{l}-20.46 \\
(0.113)\end{array}$ \\
\hline $\begin{array}{l}\text { Interaction of party } \\
\text { compet. and ethnic } \\
\text { fractionalization }\end{array}$ & $\begin{array}{c}-10.4 \\
(0.224)\end{array}$ & & & & & & & \\
\hline $\begin{array}{l}\text { Interaction of party } \\
\text { compet. and GDP per } \\
\text { capita }\end{array}$ & & & $\begin{array}{c}-1.32 \\
(0.227)\end{array}$ & & & & & \\
\hline $\begin{array}{l}\text { Assembly-elected } \\
\text { president }\end{array}$ & $\begin{array}{c}14.04 \\
(0.011) \\
\end{array}$ & & & & & & & \\
\hline Parliamentary system & $\begin{array}{c}5.25 \\
(0.318) \\
\end{array}$ & $\begin{array}{c}4.88 \\
(0.267) \\
\end{array}$ & $\begin{array}{c}9.7 \\
(0.078) \\
\end{array}$ & $\begin{array}{c}8.84 \\
(0.092 \\
\end{array}$ & $\begin{array}{l}10.26 \\
(0.004) \\
\end{array}$ & $\begin{array}{l}14.23 \\
(0.02) \\
\end{array}$ & $\begin{array}{l}21.19 \\
(0.009) \\
\end{array}$ & $\begin{array}{c}20.23 \\
(0.022) \\
\end{array}$ \\
\hline $\begin{array}{l}\text { Government } \\
\text { cohesiveness }\end{array}$ & $\begin{array}{c}0.009 \\
(0.128) \\
\end{array}$ & $\begin{array}{c}0.009 \\
(0.164)\end{array}$ & $\begin{array}{c}0.01 \\
(0.119)\end{array}$ & $\begin{array}{l}0.013 \\
(0.05)\end{array}$ & $\begin{array}{l}0.011 \\
(0.05)\end{array}$ & $\begin{array}{l}0.011 \\
(0.19)\end{array}$ & $\begin{array}{l}0.019 \\
(0.10)\end{array}$ & $\begin{array}{l}0.018 \\
(0.14)\end{array}$ \\
\hline $\begin{array}{l}\text { Ethnolinguistic } \\
\text { fractionalization }\end{array}$ & $\begin{array}{c}20.47 \\
(0.244)\end{array}$ & $\begin{array}{c}3.34 \\
(0.738)\end{array}$ & $\begin{array}{c}5.26 \\
(0.601)\end{array}$ & $\begin{array}{l}4.29 \\
(0.68\end{array}$ & $\begin{array}{l}29.46 \\
(0)\end{array}$ & $\begin{array}{c}33.04 \\
(0)\end{array}$ & $\begin{array}{c}6.24 \\
(0.71)\end{array}$ & $\begin{array}{c}5.73 \\
(0.73)\end{array}$ \\
\hline $\begin{array}{l}\text { Interacting ethnic } \\
\text { frac. and point } \\
\text { exporters }\end{array}$ & & & & & & & & \\
\hline $\begin{array}{l}\text { Interacting ethnic } \\
\text { frac. and party } \\
\text { competitiveness }\end{array}$ & & & & & & & $\begin{array}{c}24.3 \\
(0.105)\end{array}$ & $\begin{array}{c}23.02 \\
(0.14)\end{array}$ \\
\hline $\begin{array}{l}\text { Dummy (income vs. } \\
\text { expenditures) }\end{array}$ & $\begin{array}{c}5.82 \\
(0.149) \\
\end{array}$ & $\begin{array}{c}6.34 \\
(0.124) \\
\end{array}$ & $\begin{array}{c}7.12 \\
(0.099) \\
\end{array}$ & $\begin{array}{c}7.40 \\
(0.088) \\
\end{array}$ & $\begin{array}{c}7.93 \\
(0.02) \\
\end{array}$ & $\begin{array}{c}6.03 \\
(0.08) \\
\end{array}$ & $\begin{array}{c}5.07 \\
(0.17) \\
\end{array}$ & $\begin{array}{c}5.22 \\
(0.17) \\
\end{array}$ \\
\hline $\begin{array}{l}\text { Dummy (household } \\
\text { vs. person) }\end{array}$ & $\begin{array}{c}5.3 \\
(0.199) \\
\end{array}$ & $\begin{array}{l}-1.33 \\
(0.782)\end{array}$ & $\begin{array}{c}4.47 \\
(0.33)\end{array}$ & $\begin{array}{l}4.27 \\
(0.37 \\
\end{array}$ & $\begin{array}{l}-0.55 \\
(0.90 \\
\end{array}$ & $\begin{array}{c}1.00 \\
(0.85)\end{array}$ & $\begin{array}{c}1.08 \\
(0.85)\end{array}$ & $\begin{array}{c}0.78 \\
(0.89)\end{array}$ \\
\hline $\begin{array}{l}\text { Dummy (gross } \\
\text { income vs. net) }\end{array}$ & $\begin{array}{l}-0.788 \\
(0.742) \\
\end{array}$ & $\begin{array}{l}-0.745 \\
(0.744) \\
\end{array}$ & $\begin{array}{c}-0.56 \\
(0.809) \\
\end{array}$ & $\begin{array}{l}-0.385 \\
(0.87 \\
\end{array}$ & $\begin{array}{l}-1.61 \\
(0.42) \\
\end{array}$ & $\begin{array}{l}-0.69 \\
(0.73) \\
\end{array}$ & $\begin{array}{l}-1.25 \\
(0.50) \\
\end{array}$ & $\begin{array}{l}-1.13 \\
(0.55) \\
\end{array}$ \\
\hline $\begin{array}{l}\text { Medium commodity } \\
\text { dependent }\end{array}$ & & & & & $\begin{array}{c}6.64 \\
(0.035)\end{array}$ & $\begin{array}{c}7.43 \\
(0.06)\end{array}$ & $\begin{array}{c}7.95 \\
(0.064) \\
\end{array}$ & $\begin{array}{c}7.93 \\
(0.068)\end{array}$ \\
\hline $\begin{array}{l}\text { Highly commodity } \\
\text { dependent }\end{array}$ & & & & & $\begin{array}{l}-1.57 \\
(0.51)\end{array}$ & $\begin{array}{c}1.07 \\
(0.76)\end{array}$ & $\begin{array}{c}2.90 \\
(0.46)\end{array}$ & $\begin{array}{c}2.80 \\
(0.48)\end{array}$ \\
\hline Point source exporter & & & & $\begin{array}{c}4.1 \\
(0.06) \\
\end{array}$ & & & & \\
\hline Orthodox Christian & & & & & & $\begin{array}{l}-16.3 \\
(0.21)\end{array}$ & $\begin{array}{l}-24.8 \\
(0.11)\end{array}$ & $\begin{array}{l}-23.4 \\
(0.15)\end{array}$ \\
\hline New Christian & & & & & & $\begin{array}{l}-6.98 \\
(0.088)\end{array}$ & $\begin{array}{l}-11.52 \\
(0.047)\end{array}$ & $\begin{array}{l}-10.6 \\
(0.11)\end{array}$ \\
\hline Buddhist/Hindu & & & & & & $\begin{array}{l}-15.6 \\
(0.098)\end{array}$ & $\begin{array}{l}0.915 \\
(0.94)\end{array}$ & $\begin{array}{c}4.54 \\
(0.75)\end{array}$ \\
\hline $\begin{array}{l}\text { Christian/African } \\
\text { traditional }\end{array}$ & & & & & & $\begin{array}{c}6.04 \\
(0.064)\end{array}$ & $\begin{array}{c}4.67 \\
(0.21)\end{array}$ & $\begin{array}{c}4.57 \\
(0.22)\end{array}$ \\
\hline No dominant religion & & & & & & $\begin{array}{l}-6.98 \\
(0.002)\end{array}$ & $\begin{array}{l}-8.42 \\
(0.00)\end{array}$ & $\begin{array}{c}-7.93 \\
(0.007)\end{array}$ \\
\hline Population density & & & & & & & & -0.009 \\
\hline
\end{tabular}




\begin{tabular}{|l|c|c|c|c|c|c|c|c|}
\hline & & & & & & & & $(0.73)$ \\
\hline Constant & $\begin{array}{c}15.318 \\
(0.902)\end{array}$ & $\begin{array}{c}54.03 \\
(0.627)\end{array}$ & $\begin{array}{c}18.67 \\
(0.865)\end{array}$ & $\begin{array}{c}-16.71 \\
(0.88\end{array}$ & $\begin{array}{c}22.47 \\
(0.84)\end{array}$ & $\begin{array}{c}220.5 \\
(0.225)\end{array}$ & $\begin{array}{c}290.2 \\
(0.15)\end{array}$ & $\begin{array}{c}282.7 \\
(0.16)\end{array}$ \\
\hline $\begin{array}{l}\text { Number of } \\
\text { observations }\end{array}$ & 73 & 78 & 73 & 73 & 67 & 65 & 65 & 65 \\
\hline $\mathrm{R}^{2}$ & 0.29 & 0.13 & 0.25 & 0.27 & 0.52 & 0.62 & 0.64 & 0.64 \\
\hline RMSE & 9.048 & 9.56 & 9.2 & 9.1 & 7.1 & 6.7 & 6.61 & 6.68 \\
\hline
\end{tabular}

Note: Levels of significance between brackets. All regressions are run with robust (Huber/White) standard errors. Omitted category is low commodity dependent country. In equations with religion included, the omitted religion is Muslim. All democracy variables are theee-year lagged averages with the exception of the variable in formulation 2 .

Finally, adding population density in formulation $\mathbf{8}$, as we have done for the world as a whole, leaves results from formulation 7 unchanged. In three last regressions, $\mathrm{R}^{2}$ is much greater than what we have started with: it went up from less than 0.3 to about 0.65 .

In conclusion, when we restrict our sample to African countries alone and try to find out what makes inequality different among them, the results are much weaker than for the world as a whole partly (or entirely?) because of a limited number of observations and lack of variability across characteristics in the sample. In contrast to the results for the world, we find that parliamentary system us more likely to lead to inequality than the presidential. We reconfirm the strong effect of fractionalization. But, more importantly, the effect of ethnic fractionalization is found to be much weaker or nil as countries become more democratic. This pinpoints to one of the conventional ways in which negative features of ethnic fractionalization are reduced, and shows that this works in Africa as well. The effect however is probably not very strong since for the world as a whole we did not find that democratization does away with the role of ethnic fractionalization in Africa (see equation 10 in Table 4). It is only when our sample was limited to African countries that we did find that, within them, being democratic or not does make a difference. 
Table 7. Sub-Saharan African countries according to dominant religion

\begin{tabular}{|c|c|c|c|c|}
\hline & $\begin{array}{l}\text { Number of } \\
\text { countries } \\
\text { (percent) }\end{array}$ & Countries & $\begin{array}{l}\text { Percent of data } \\
\text { points (number } \\
\text { of } \\
\text { observations) }\end{array}$ & $\begin{array}{l}\text { Average } \\
\text { Gini }\end{array}$ \\
\hline Catholic & $1(3)$ & Seychelles & 2 & \\
\hline Orthodox & $1(30$ & Ethiopia & 3 & \\
\hline New Christianity & $7(18)$ & $\begin{array}{l}\text { Gabon } \\
\text { Lesotho } \\
\text { Malawi } \\
\text { Rwanda } \\
\text { Uganda } \\
\text { South Africa } \\
\text { Zambia }\end{array}$ & 27 & 51 \\
\hline Muslim & $8(21)$ & $\begin{array}{l}\text { Djibouti } \\
\text { Guinea } \\
\text { Gambia } \\
\text { Mali Mauritania } \\
\text { Niger } \\
\text { Sudan } \\
\text { Senegal }\end{array}$ & 18 & 44 \\
\hline Buddhism/Hinduism & $1(3)$ & Mauritius & 3 & \\
\hline $\begin{array}{l}\text { African Christianity } \\
\text { and traditional } \\
\text { religion }\end{array}$ & $7(18)$ & $\begin{array}{l}\text { Angola } \\
\text { Botswana } \\
\text { CAR } \\
\text { Cameroom } \\
\text { Kenya } \\
\text { Madagascar } \\
\text { Zimbabwe }\end{array}$ & 17 & 51 \\
\hline $\begin{array}{l}\text { Mixed (or no } \\
\text { dominant) religion }\end{array}$ & $14(36)$ & $\begin{array}{l}\text { Benin } \\
\text { Bourkina Faso } \\
\text { Cote d'Ivoire } \\
\text { Congo Rep. } \\
\text { Ghana } \\
\text { Guinea-Bissau } \\
\text { Mozambique } \\
\text { Nigeria } \\
\text { Sierra Leone } \\
\text { Chad } \\
\text { Togo } \\
\text { Tanzania } \\
\text { Zaire (DRC) }\end{array}$ & 31 & 43 \\
\hline
\end{tabular}




\section{In lieu of conclusions: some reflections on Africa and the role of ethnicity}

We set out with one objective and one hypothesis in mind. The objective was to check whether determinants of inequality in Africa are different from the rest of the world. In other words, to find out if there is something in "Africaness" which makes it conducive to high inequality. We have concluded that it is interaction between high ethnic fractionalization and Africa that is particularly liable to result in high inequality: the effect of the same degree of fractionalization on inequality is greater in Africa than elsewhere and is independent of level of income and democracy (in other words, it is not explained by low levels of income and democracy in Africa). This view was further confirmed by the finding that even within Africa, greater ethnolinguistic fractionalization was conducive to greater inequality. Second, our hypothesis was that there are political factors behind the presence of high inequality in Africa. And indeed if ethnicity is viewed as a very effective (and economical) way around which to organize a political group, ${ }^{47}$ then the break up of the polity into many ethnicities can be regarded as a proxy for political decision making based on attempts to maximize the spoils, or the fruits of progress, for one's own constituents. The two factors are then twined: the political sources of inequality are key, and the politics works through ethnicity (and religion). This would be a shorthand of the "ethnicity-as-politics" (EP) hypothesis. Yet we also find evidence that both in Africa and the world, the power of EP diminishes as countries become more democratic.

The ethnic fragmentation variable as an explanation for many evils in this world (e.g. low growth in Africa in Easterly and Levine (1997), partition between the states in Alesina and Spolaore (1997), corruption in Mauro (1995), unevenness in the provision of public goods in Alesina, Baqir and Easterly (1997), political instability in Arnett (2000)) has enjoyed something of a vogue recently. As Mark Mazower (1998, p.389-90) writes in the context of transition from Communism: "After 1989, Western commentators became transfixed by nationalism. As national memories and old hatreds resurfaced, it was easy to see the revival of nationalism as the return of history and the root of...future troubles.

\footnotetext{
${ }^{47}$ As argued for example in Addison and Murshed (2003).
} 
The study of ethnic minorities has now become a growth industry for academics, security experts and international lawyers. Communist elites may have made an easy switch to new roles as nationalist figureheads, but their Western observers were not far behind them, expertly retooling their Cold War analytic skills." This is understandable because the end of the Cold War has brought ethnicity and religion back with a vengeance as key factors that shape political and social life in many parts of the world. Thus, clearly, there is something to ethnicity. In addition, to econometricians, ethnicity presents that rare variable which is both meaningful (in terms of explanatory power) and is exogenous. ${ }^{48}$ The attractiveness of the variable was confirmed by its apparent strong significance in many studies, including this one. Almost no matter how hard one tries, ethnicity tends to "survive" all econometric tests, and reformulations of the hypotheses.

Yet there is something deeply unsatisfactory in the explanations that involve ethnicity and ethnic fragmentation. Two things are unsatisfactory: lack of policy implications, and lack of knowledge of mechanisms (channels) through which ethnicity affects outcomes. Saying that ethnic fragmentation means slower growth or higher inequality to a policy maker from an ethnically heterogeneous country is saying that either his country is doomed, or that it needs to be broken down into several ethnically homogeneous countries. The economic policy-maker can then go fishing since neither solution requires him. The first solution requires no one, the second requires soldiers.

But the lack of knowledge regarding the channels whereby ethnicity affects the outcomes is an even greater concern. Let us suppose that indeed ethnicity has the impact that is ascribed to it, that EP hypothesis holds, and moreover that we are not interested in policy advice but simply in a positive description of a phenomenon. We still need to know-and do not-"how" ethnicity does what it does. Compare this with democracy. When we say that an increase in democracy is associated with $\mathrm{X}$, we more or less know

\footnotetext{
${ }^{48}$ Unless, of course, one takes a rather extreme position of holding that high inequality in conditions of ethnic fragmentation would lead to a civil war that, in turn, might alter ethnic composition of the country. Although the assumption is fairly strong, it is, unfortunately, not too removed from recent actual developments in several countries. There are also views among political scientists that endogeneity is an endogeneous variable in the sense that it is politically constructed (I owe this point to Nicolas van de Walle.) However, for our purposes, it is unlikely that inequality will have a direct effect on ethnic composition of the country.
} 
what we are talking about because we know what "democracy" means and we have a number "unpacked" measures of democracy — that is, channels through which democracy affects other variables. We have measures of media freedom, the way that the parliament or the chief executive are elected, whether the system is based on proportional representation or single-district majority; we have measures of social involvement in decision making, number of NGOs, extent of the power of the elite. Some of these "unpackaged" measures of democracy were used in this paper too.

But this is far from being the case with ethnicity. Other than for a hypothesis that ethnicity makes working out consistent macro policies difficult, or that a competition for spoils develops in such a way that every group when it comes to power tends to transfer resources to its own members, we know very little about how "ethnicity" gets translated into inefficient outcomes. As we have argued here as well, ethnicity works well, and because it works well we treat it as a proxy for something we are unable to test.

The explanations about what ethnicity proxies for and what are the mechanisms through which it works mentioned here or elsewhere are pure hypotheses-we are not able to directly measure nor test any of them. ${ }^{49}$ Moreover, when groups compete for spoils, it need not necessarily be a competition between different ethnic groups: the basis for group formation could be very different. But if ethnicity represents a more secure basis for coalition formation, the question is "why"- -because the costs of defection are higher, enforcement is easier, level of trust is greater? And if so, can't we test these hypotheses directly?

How weak ethnicity is as an explanation despite its prime facie plausibility can be illustrated on the example of the Alesina and Spolaore (1997) paper on nation formation. After the break up of the Soviet Union, Yugoslavia, Ethiopia and Czechoslovakia (together with the creation of the European Union), the papers that sought to "explain" the optimal number of states in the world became popular. Alesina and Spolaore (1997)

\footnotetext{
${ }^{49}$ As Easterly and Levine (1995, p. 15) write, "We suspect [my emphasis] that ethnically fragmented societies are prone to competition by the different ethnic groups and have difficulty agreeing on public goods like infrastructure, education, and good policies."
} 
paper derives the number of the states in the world as a result of a trade-off between similarity of preferences between different (ethnic) groups, and decreasing cost of provision of public goods. There is thus an optimal point where gains from lower cost of provision of public goods and larger market size are offset by higher disutility from association with people whose preferences we do not share. The explicit assumption is that the similarity of preferences is decreasing in distance. ${ }^{50}$ But that approach is clearly at odds with reality (and literature) on ethnic conflict and civil war. Wars are not fought between vastly different peoples. Overwhelming majority of civil wars are fought between people who are objectively very close - often so close that the outsiders have a hard time figuring out what the argument is about. Thus, Tutsi fight with Hutus, Serbs with Croats, Tamils with Hindus, Basques with Spaniards, all people whose preferences should be very similar. Therefore, what appears at first sight plausible - that people belonging to ethnicities that live close by should share the same preferences and live in the same state-becomes very doubtful when we look at it more carefully.

Recently, Durlauf (2002, p. 474) has questioned the use of the ethnicity variable by pointing out how it is used to mean different things. He shows how Knack and Keefer (2001) use ethnolinguistic fractionalization to instrument for social capital (lack of it) which in turn affects growth. But, in a very similar context, Easterly and Levine (1997) use ethnolinguistic fractionalization as an instrument for ethnic conflict which makes public good formation more difficult and decelerates growth. Now, as Durlauf writes, even if we grant that public good formation may be related to social capital, "these two papers...use the same variable as an instrument for different causal growth determinants." Or in other words, there is no unanimity for what ethnic fractionalization really stands for.

\footnotetext{
50 “...the average cultural or preference distance between individuals is likely to be positively correlated with the size of the country" (Alesina and Spolaore, 1997, p. 1029), or "...to assume that individuals who are close to each other in preferences are also close to each other geographically (ibid, p. 1031). Unwittingly, Alesina and Spolaore have rediscovered Montesquieu who in L'esprit des Lois, some two hundred years ago, argued precisely that climate (and thus physical distance) determines people's character. Thus, since climate in Europe changes gradually as one moves from the South to the North, European peoples are more similar to each other, while in Asia, where different peoples live far from each other, either in harsh or warm climates, they are either warlike or effeminate and thus very different from each other.
} 
When the "unpacking" of the ethnicity variable begins—when one asks questions such as "in what way does ethnic fragmentation manifest itself, and makes policy-making or coalition-formation different from what it would have been in ethnically homogeneous societies" and tests for this directly—we would have made more progress in the understanding of the problem. Such understanding is more easily obtainable from individual case studies. Unfortunately, it is very difficult to move from case studies, each of which is often a sui generis case ${ }^{51}$ to a generalization that can be measured, and used as a variable in an empirical study.

A useful approach for future research would be to try to "unpack" ethnicity, in order words to try to find out what exactly the variable represents and through what channels it affects inequality, growth and other variables which it has found to be associated with.

\footnotetext{
${ }^{51}$ A very useful case study is the one by Nkurunziza and Ngaruko (2002) that assesses the role of ethnic conflict in destroying basis for any growth in Burundi. But again, however, useful for Burundi, it is difficult to see how one could move from that one study to a more generalized approach.
} 


\section{REFERENCES}

Addison Tony and Mansoor S. Murshed (2003), "Debt Relief and Civil War", Journal of Peace Research, March, vol. 40, no. 2, pp. 159-176.

Alesina, Alberto and Enrico Spolaore (1997), "On the number and size of nations", Quarterly Journal of Economics, vol. 112, no. 4 (November 1997), pp. 1027-56.

Alesina, Alberto, Reza Baqir and Wiliam Easterly (1999), "Public Goods and Ethnic Divisions", Quarterly Journal of Economics vol. 114, no. 4 (November ), pp. 1243-84.

Allen, C,. (1999), "Warfare, endemic violence and state collapse in Africa", Review of African Political Economy, vol. 26, pp. 361-384.

Annett, Anthony (2000), "Social Fractionalization, Political Instability and the Size of Government", IMF Working Paper, No. 82/2000.

Arrighi, Giovanni (2001), “The African Crisis”, New Left Review, May-June 2002.

Bairoch, Paul (1997), Victoires et déboires, Histoire économique et sociale du monde du $X V I^{e}$ siècle à nos jours, Paris:Folio Histoire Gallimard.

Barrett, David B. ed. (1982), World Christian Encyclopedia, New York: Oxford University Press.

Bates, Robert (1981), Markets and States in Tropical Africa: The Political Basis of Agricultural Policy, Berkeley, CA: University of California University Press.

Beck, T., G. Clarke, A. Groff, P. Keefer, and P. Walsh, 2000, "New Tools and New Tests in Comparative Political Economy: The Database of Political Institutions", World Bank Policy Research Working Paper No. 2283.

Behrendt, Stephen D., David Eltis and David Richardson (2001), "The costs of coercion: African agency in the pre-modern Atlantic world", Economic History Review, vol. 54, No. 3, pp. 454-476.

Birdsall, Nancy and Amar Hamoudi (2002), "Commodity dependence, trade and growth: When openness is not enough", Center for Global Development Paper No. 7, May 2002, Washington, D.C. Available at http://www.cgdev.org/pubs/workingpapers.html.

Bratton, M. and Nicholas van de Walle (1998), "Neopatrimonial regimes and political transition in Africa" in P. Lewis (ed.), Africa: The Dilemmas of Development and Change, Boulder, Colorado: Westview. 
Christiaensen, Luc, Lionel Demery and Stefano Paternostro (2002), "Growth, distribution and poverty in Africa: Messages from the 1990s, World Bank Economic Review, forthcoming.

Demery, Lionel and Lyn Squire (1996), "Macroeconomic Adjustment and Poverty in Africa: An Emerging Picture", World Bank Research Observer v11, n1 (February 1996): $39-59$.

Durlauf, Steven (2002), “On the Empirics of Social Capital”, Economic Journal v112, No. 483 (November 2002), pp. F459-79.

Dollar, David and Aart Kraay (2002), "Growth is Good for the Poor", Journal of Economic Growth vol. 7, No. 3 (September): pp. 195-225

Gelb, Alen (2001), "South Africa's role and importance in Africa and for the development of the African agenda", Johannesburg: The Edge Institute.

Easterly, Bill and Ross Levine (1997), “Africa’s Growth Tragedy: Policies and Ethnic Divisions”, Quartetly Journal of Economics, November, pp. 1203-1250.

Easterly, Bill (2002) "Inequality Does cause underdevelopment", Center for Global Development, Working Paper No. 1.

Fields, Gary (2001), Distribution and development: A new look at the developing world, Russell Sage Foundation and MIT Press.

Gradstein, Mark, Branko Milanovic and Yvonne Ying (2001), Democracy, ideology and Income Inequality: An Empirical Analysis, World Bank Policy Research Working Papers Series No. 2561, February.

Higgins, Matthew and Jeffrey Williamson (1999), "Explaining inequality the world round: Cohort size, Kuznets curve, and openness”, June 1999. Available at www.ssrn.com.

Hobson, John A. (1965 [1902]), Imperialism, Ann Arbor Paperbacks, The University of Michigan Press.

Ivaschenko, Oleksiy (2002), "Growth and Inequality: Evidence from Transitional Economies", mimeo.

Knack S. and Phil Keefer (1997), "Does Social Capital have an Economic Impact? A Cross-country Investigation”, Quarterly Journal of Economics, vol. 1122 (4), pp. 202943. 
Kuznets, Simon (1965 [1954]), "Regional economic trends and levels of living”, in Simon Kuznets, Economic Growth and Structure: Selected Essays, New Delhi: Oxford \& IBH Publishing Company.

Luiz, John (2002), “The New Partnership for African Development: Africa's response to Underdevelopment", mimeo.

Mandel, Ernest (1962), Traite d'économie politique marxiste, Paris : 10/18.

Mauro, Paul (1995), “Corruption and Growth”, Quartetly Journal of Economics, November, vol. 110, pp. 681-712.

Mazower, Mark (1998), Dark Continent, New York: Vintage books.

Milanovic, Branko (2002), "True world income distribution, 1988 and 1993: First calculation based on household surveys alone", The Economic Journal, vol. 112, No. 476, January 2002, pp. 51-92.

Milanovic, Branko (forthcoming), "Worlds Apart: Inter-national and World Inequality, 1950-2000”. Available at www.worldbank.org/research/inequality.

Mkandawire, Thandika (2002), "The Terrible Toll of Post-colonial Rebel Movements in Africa: Towards an Explanation of the Violence against the Peasantry", Journal of Modern African Studies, vol. 40, No.2, pp. 181-215.

Murshed, Mansoob S. (2002), "On natural resource abundance and underdevelopment", mimeo, version April 14, 2002.

Nkurunziza, Janvier and Floribert Ngaruko (2002), "Explaining Growth in Burundi, 1960-2000", Center for the Study of African Economies, Oxford, Working Paper No. 2002-03. Available at http://www.econ.ox.ac.uk/CSAEadmin/workingpapers/pdfs/200203text.pdf, Draft (April 2002).

Van de Walle, Nicolas (1994 ), "Political Liberalization and Economic Policy Reform in Africa", World Development v22, n4 (April 1994): 483-500

Woolcock, Michael, Lant Pritchett and Jonathan Isham (2001), "The Social Foundations of Poor Economic Growth in Resource-Rich Countries” in Richard M. Auty (ed.), Resource Abundance and Economic Development, Oxford: Oxford University Press.

World Bank (1981), Accelerated Development in Sub-Saharan Africa: An Agenda for Action, Washington, D.C.: World Bank.

Wesseling, H. L. (1996), Divide and Rule: The Partition of Africa, 1880-1914, Westport, Conn.: Praeger. 
ANNEX 1. List of Sub-Saharan African surveys conducted around 1998 (and used here)

\begin{tabular}{|l|l|l|l|}
\hline Country & Year & Welfare aggregate & Name of Survey \\
\hline Zambia & 1998 & Expenditure & $\begin{array}{l}\text { Living Condition Monitoring } \\
\text { Survey }\end{array}$ \\
\hline Nigeria & $1996 / 97$ & Expenditure & National consumer survey 1996 \\
\hline Ghana & 1998 & Expenditure & Ghana Living Standards Survey \\
\hline Gambia & 1998 & Expenditure & Household survey 1998 \\
\hline Madagascar & 1999 & Expenditure & $\begin{array}{l}\text { Enquete Prioritaire Aupres des } \\
\text { Menages }\end{array}$ \\
\hline Uganda & 1996 & Expenditure & National Integrated HH survey \\
\hline Burkina Faso & 1998 & Expenditure & Enquete prioritaire II \\
\hline Lesotho & 1995 & Expenditure & Household Budget Survey \\
\hline Kenya & 1997 & Expenditure & Welfare Monitoring Survey \\
\hline Cote d'Ivoire & 1998 & Expenditure & $\begin{array}{l}\text { Enquete Niveau de Vie des } \\
\text { Menages }\end{array}$ \\
\hline Niger & 1995 & Expenditure & $\begin{array}{l}\text { Enquête permanente de } \\
\text { conjoncture économique et sociale }\end{array}$ \\
\hline Zimbabwe & $1995-96$ & Expenditure & $\begin{array}{l}\text { Income, Expenditure and } \\
\text { Consumption Survey 1995-96 }\end{array}$ \\
\hline Malawi & $1997-98$ & Expenditure & $\begin{array}{l}\text { Malawi Integrated Household } \\
\text { Survey 1997-98 }\end{array}$ \\
\hline Cameroon & 1996 & Expenditure & $\begin{array}{l}\text { Enquete camerounaise des } \\
\text { menages 1996 }\end{array}$ \\
\hline Angola & 1995 & Expenditures & $\begin{array}{l}\text { Inquerito Prioritario Sobre as } \\
\text { Condicoes de Vida dos } \\
\text { Domicilios }\end{array}$ \\
\hline Burundi & 1998 & Expenditures & $\begin{array}{l}\text { Etude nationale sur les conditions } \\
\text { de la vie des populations }\end{array}$ \\
\hline Comoros & 1995 & Expenditures & $\begin{array}{l}\text { Enquete exploratoire budget } \\
\text { consommation }\end{array}$ \\
\hline Ethiopia & 1998 & Expenditures & Welfare Monitoring Survey 3 \\
\hline Mauritania & 2000 & Expenditures & $\begin{array}{l}\text { Enquete Permanente sur les } \\
\text { Conditions de Vie des Menages. }\end{array}$ \\
\hline
\end{tabular}


ANNEX 2. The list of sub-Saharan African countries with available Gini observations

\begin{tabular}{|c|c|c|c|}
\hline Country & Average Gini & Standard deviation & $\begin{array}{l}\text { Number of } \\
\text { observations }\end{array}$ \\
\hline Angola & 40.2 & 0.0 & 1 \\
\hline Botswana & 58.6 & 6.2 & 2 \\
\hline Burkina Faso & 46.5 & 6.9 & 3 \\
\hline Cameroon & 46.1 & 4.1 & 2 \\
\hline Central African R. & 57.3 & 3.2 & 2 \\
\hline Cote d'Ivoire & 38.4 & 4.5 & 4 \\
\hline Djibouti & 38.5 & 0.6 & 2 \\
\hline Ethiopia & 44.8 & 5.1 & 3 \\
\hline Gabon & 59.1 & 3.0 & 4 \\
\hline Gambia & 44.4 & 7.7 & 2 \\
\hline Ghana & 35.2 & 2.7 & 7 \\
\hline Guinea & 44.7 & 3.7 & 3 \\
\hline Guinea-Bissau & 55.3 & 1.2 & 2 \\
\hline Kenya & 54.2 & 6.5 & 4 \\
\hline Lesotho & 61.2 & 4.0 & 4 \\
\hline Madagascar & 45.0 & 6.3 & 4 \\
\hline Malawi & 55.8 & 8.8 & 2 \\
\hline Mali & 54.0 & 0.0 & 1 \\
\hline Mauritania & 40.3 & 1.9 & 3 \\
\hline Mauritius & 35.0 & 12.0 & 4 \\
\hline Niger & 40.2 & 9.0 & 3 \\
\hline Nigeria & 42.1 & 6.2 & 9 \\
\hline Rwanda & 27.9 & 1.7 & 3 \\
\hline Senegal & 54.0 & 2.0 & 3 \\
\hline Seychelles & 46.5 & 0.7 & 2 \\
\hline Sierra Leone & 59.5 & 4.9 & 2 \\
\hline South Africa & 60.9 & 2.0 & 4 \\
\hline Sudan & 39.4 & 0.9 & 2 \\
\hline Tanzania & 42.2 & 14.0 & 6 \\
\hline Uganda & 40.1 & 2.6 & 4 \\
\hline Zambia & 49.9 & 3.6 & 6 \\
\hline Zimbabwe & 51.9 & 7.0 & 2 \\
\hline
\end{tabular}

Note: Includes data from WIDER complemented with WYD data from B. Milanovic. 